\title{
斜張橋ケーブルを対象とした併用ダンパー方式の 減衰評価手法とその設計法に関する研究
}

\author{
米田昌弘 ${ }^{1} \cdot$ 望月秀之 $^{2} \cdot$ 瀬戸内秀規 $^{3}$ \\ ${ }^{1}$ 正会員 工博 川田工業俐）技術本部研究室長（广 550 大阪市西区北堀江 1-22-19） \\ ${ }^{2}$ 正会員 川田工業( 㑣) 技術本部研究室 (同 上) \\ ${ }^{3}$ 正会員 工修 川田工業保 技術本部研究室（同 上）
}

\begin{abstract}
風による斜張橋ケーブルの振動とその制振に関する検討は今までにも増して重要となりつつあり，大規模な長 大斜張橋では，空力的対策に加え， 1 本のケーブルに 2 基のダンパーを設置する併用ダンパー方式を対策案の一 つとして検討する機会が增加するものと推察される。このような状況を踏まえ，本文では，併用ダンパー方式を 採用した場合の減衰評価手法を提示している。また，提案した減衰評価手法を適用して，併用ダンパー方式の特 徵を明らかにするとともに設計上の留意点についても言及し，斜張橋ケーブルの制振対策に関する有用な知見を 報告している。
\end{abstract}

Key Words : cable, cable-stayed bridge, vibration control, damper

\section{1 。まえがき}

周知の如く, 斜張橋ケーブルの風による振動に対処す る方法として最近ではケーブル端部付近にダンパーを設 置する方式が主要な制振対策として位置づけられつつあ る ${ }^{11}$.ダンパーを設置する手法としては, 荒津大橋や天保 山大橋で採用されているオイルダンパー方式2), 幸魂大 橋や東名足柄橋等で採用されている粘性せん断型ダン パー方式(3)が最も一般的であるが, 最近では高減衰ゴム を設置する方式)も開発され実橋ケーブルへの適用例も 報告されている．また，厳密にはダンパー方式に分類で きないが, 渦励振など比較的励振力の弱いケーブル振動 に対して，弾性シール材の設置で対処する事例5も増加 している.

これら各種ダンパー方式の特徴として，たとえば，オ イルダンパー方式や粘性せん断型ダンパー方式では, 確 実に減衰を付加できるものの, ケーブルのサグ変化など にともなう 2 次応力の低減は期待できない. 一方, 高減 衰ゴム方式ではケーブルのサグ変化にともなう 2 次応力 にもある程度対処できるが, ケーブルに付加される構造 減衰の最大值は, オイルダンパー方式や粘性せん断型ダ ンパー方式に比べ,一般に小さくなる.さらに, 弾性シー ル材を設置する手法では, その本来の機能からケーブル のサグ変化にともなう 2 次応力の低滅には十分に対処で きるが, 弾性シール材のばね定数は非常に大きく, ケー ブルに付加される構造隇衰の最大值は高減衰ゴム方式よ りもさらに小さいものとなる.
したがって，実務設計にあたっては，対象とするケー ブル振動の励振力と上述した各方式のそれぞれの特徴を 考え合わせて，実橋で採用すべきダンパーを具体的に選 定することとしている. しかしながら, 従来は最長ケー ブルが $250 \mathrm{~m}$ 程度以下の斜張橋を対象とする場合がほ とんどであり, 景観に対する配慮から高欄や自動車防護 栅高さを越えない位置に 1 基（粘性せん断型ダンパーゃ 高減衰ゴムでは 1 個，オイルダンパーでは 1 対）のダン パーを設置することによってケーブル制振が図られ，ま た実際, 風によるケーブル振動に対して十分な対処が可 能であった。これに対し, 最長ケーブルが $250 \mathrm{~m} \sim 300 \mathrm{~m}$ 程度以上の大規模な長大斜張橋では, 高欄や自動車防護 栅と同程度の高さにダンパーを設置するという条件下 で，たとえばレインバイブレーションの発現する可能性 が高い $3 \mathrm{~Hz}$ 程度以下のすべての振動モードに対して所 定の構造減衰を付加することは一般に困難である。それ ゆえ, 大規模な長大斜張橋では, ケーブル制振に関して, 2 つの設計思想が存在するものと考えられる.すなわち, 一つはケーブル表面に凹型や凸型等の粗度を付与する方 法（空力的対策の採用）であり,もう一つは, 高欄や自 動車防護柈高さは若干越えるものの， 2 基のダンパーを 併用して所定の構造減衰を付加する方法である. 実際, 中央支間長が $485 \mathrm{~m}$ で最長ケーブルが約 $215 \mathrm{~m}$ の東神 戸大橋では前者の空力的対策（ケーブル表面に適当な間 隔で小さな突起を設ける方法）が，また，中央支間長が $510 \mathrm{~m}$ で最長ケーブルが約 $285 \mathrm{~m}$ の鶴見つばさ橋では 後者の 2 基のダンパーを併用する手法（下方側に高減衰 
ゴム，上方側にオイルダンパー）がすでに採用されるに 至っている ${ }^{6), 7)}$.

近年における斜張橋の長径間化と施工実績は目覚まし く，その機能美から本形式はますます盛んに建設されて いくものと予想される．それゆえ，風によるケーブル振 動とその制振に関する検討も今までにも増して重要とな $\eta$, 大規模な長大斜張橋では, 空力的対策に加え, 1 本 のケーブルに 2 基のダンパーを設置する併用ダンパー方 式を対策案の一つとして検討する機会が増加するものと 推察される.しかしながら，1本のケーブルに 2 基のダ ンパーを設置した場合の隇衰付加効果を検討する場合，

当然のことながら，1本のケーブルに 1 個のダンパー設 置を前提とした従来の設計用減衰評価曲線(2),8) 10) はその ままでは適用できない. 一方，斜張橋ケーブルの全段に ついて複素固有值解析を実施することは，非常に繁雑で 多大の労力と費用を要する検討作業となる，それゆえ， 併用ダンパー方式を採用した場合にも適用できる減衰評 価手法の提示が，実務技術者から強く望まれていた。

このようなダンパー方式による新しいケーブル制振の 動向に配慮し, 著者らは，1 本のケーブルに 2 基のダン パーを併用する方式を採用した場合の減衰評価手法を提 示することとした．本評価手法の基本概念は，下方側ダ ンパーの寄与で上方側ダンパーの設置位置が，また，上 方側ダンパーの寄与で下方側ダンパーの設置位置がそれ ぞれ見かけ上短くなることを考慮し，従来の設計用減衰 評価曲線（1本のケーブルに 1 個のダンパーを設置した 場合の減衰評価曲線）から計算した上方側ダンパーのみ と下方側ダンパーのみによる構造減衰をそれぞれ重ね合 わせようとするものである.したがって，2 基のダンパー が併用された場合にもパソコンなどを利用すればきわめ て短時間にしかも比較的精度良くケーブルに付加される 構造減衰を推定でき，実務上の有用性もきわめて高いと 考えられる。一方, 併用ダンパー方式については鶴見つ ばさ橋での実施例があるのみで，本方式の特徵や設計上 の留意点については未だ十分に解明されているとは言え ない.そこで，提案した減衰評価手法を適用して，1本 のケーブルに 1 基のダンパーを設置した場合と 2 基のダ ンパーを併用した場合の減衰付加特性について対比を行 い，併用ダンパー方式の特徵を明らかにするとともに設 計上の留意点についても言及することとした。その結果， 斜張橋の設計や制振に携わる実務技術者にとってきわめ て有用な知見が得られたことから，ここにその結果を報 告する.

\section{2. 減衰評価手法}

細径ケーブルを使用することの多い PC 斜張橋では, 角折れ緩衝装置（弾性シール材）を施したケーブルを対

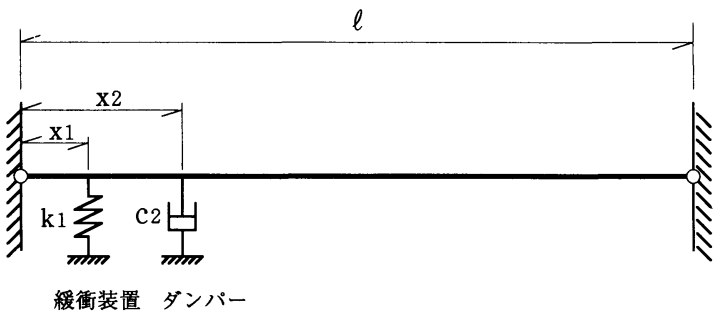

図一1 緩衝装置が併用された場合の検討モデル

象として，ダンパーによる減衰付加効果を検討すること もしばしば行われている。これは併用ダンパー方式の特 殊なケースと考えられ，当然のことながら，従来の設計 用減衰評価曲線では十分な検討を実施できない，それゆ え，本章では， 1 本のケーブルに 2 基のダンパーを設置 する併用ダンパー方式のみならず，角折れ緩衝装置が下 方側に配置され，さらに上方側にもダンパーが設置され た場合についても節を設け，ケーブルに付加される構造 減衰を従来の設計用減衰評価曲線（1 本のケーブルに 1 個のダンパーを設置した場合の減衰評価曲線）を適用し て算定する手法を提示することとする，なお，設計用減 衰評価曲線として種々のものがすでに提案されている が，本研究ではばね剛性を有するダンパーを設置した場 合にも適用できる文献 10)に示された評価式を適用する ものとした。

\section{（1）角折れ緩衝装置が併用された場合}

ケーブル定着部での疲労強度が比較的小さいケーブル を採用した斜張橋では，ケーブル定着部での疲労強度を 確保する必要から，図一 1 に示すようにケーブル端部か ら $x_{1}$ なる位置に桁側緩衝装置を設置した状態で， $x_{2}$ な る位置にダンパー（ダッシュポット）を設置した場合の 減衰付加効果を検討することもしばしば行われている. このように角折れ緩衝装置が併用された検討モデルに対 し，実務設計では設計にとって安全側の立場から桁側の 緩衝装置が設置された位置を固定点と考え，既往の設計 用減衰評価曲線を適用してダンパーによる減衰付加効果 を推定する場合が多い。しかしながら，この方法は角折 れ緩衝装置のばね定数を無限大と仮定した場合に相当 し，それゆえ，ダンパーの減衰付加特性に及ぼす緩衝装 置の影響を詳細に検討する必要がある場合には複素固有 值解析を実施せざるを得なかった。

これに対し，ここで提示する最初の手法（後述する手 法と区別するため, 本文では METHOD-1 と呼称する) は, 析側の緩衝装置の影響でダンパーの設置位置 $x_{2}$ が見 かけ上短くなると考えて, ケーブルに付加される構造減 衰を推定しようとするものである，なお，角折れ緩衝装 置は一般に塔側にも設置されるが, 通常, 桁側に比べて 


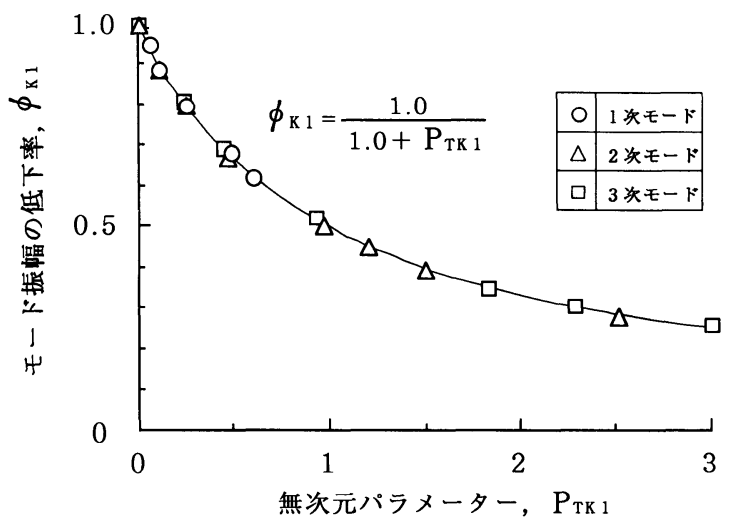

図一2 無次元パラメーター $P_{T K 1}$ とモード振幅の低下率 $\phi_{K 1}$ の関係

ケーブル端部からの取り付け位置は短く，また，ばね定 数は大きい.したがって, 以下の議論にあたっては, 塔 側の緩衝装置が設置された位置をケーブル端部と仮定す ることとしている.

今，種々の構造諸元を有する長さ $100 \mathrm{~m}$ のケーブルを 対象として, 緩衝装置の取り付け位置 $x_{1}$ とそのばね定数 $k_{1}$ を変化させて固有振動解析を実施すれば， $x_{1}$ 点におけ るモード振幅の低下率 $\phi_{k 1}$ （ばね定数が $k_{1}$ なる場合の モード振幅/ばねを設置しない場合のモード振幅）と無次 元パラメーター $P_{T K 1}$ の関係が図一2 2 ように得られる. なお，無次元パラメーター $P_{T K 1}$ は次式で定義され，ばね 剛性とケーブル張力に起因した剛性との比を表すもので ある ${ }^{10)}$.

$$
P_{T K 1}=\frac{x_{1} \cdot\left(\ell-x_{1}\right) \cdot k_{1}}{T \cdot \ell}
$$

ここに，Tはケーブル張力， $\ell$ はケーブル長である. 図 -2 上り,モード振幅の低下率 $\phi_{k 1}$ と無次元パラメー ター $P_{T K 1}$ には，モード次数に係わらず，以下の関係が成 立することがわかる。

$$
\phi_{k 1}=\frac{1.0}{1.0+P_{T K 1}}
$$

したがって，桁側緩衝装置を併用した場合，上方側オイ ルダンパーの取り付け位置 $x_{2}$ は,

$$
\phi_{k 1} \times \sin \left(n \pi x_{1} / \ell\right)=\sin \frac{n \pi\left(x_{1}-x_{k 1}\right)}{\ell-x_{k 1}}
$$

なる関係式から誘導した，次式で計算される $x_{k 1}$ なる距 離だけ短くなると仮定できよう.

$$
x_{k 1}=\frac{n \pi x_{1}-\ell \times \sin ^{-1}\left\{\phi_{k 1} \times \sin \left(n \pi x_{1} / \ell\right)\right\}}{n \pi-\sin ^{-1}\left\{\phi_{k 1} \times \sin \left(n \pi x_{1} / \ell\right)\right\}}
$$

ここに，nはモード次数である.

以上の議論より，対象とした検討モデル（下方側に緩 衝装置，上方側にオイルダンパーが設置されたモデル） は図一 3 に示したモデル(長さ $\ell-x_{k 1}$ なるケーブルの $x_{2}$

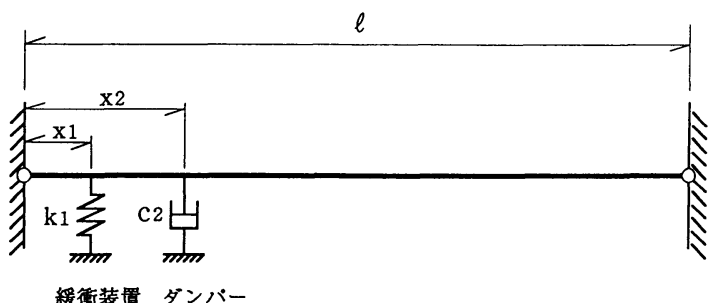

』等価モテル

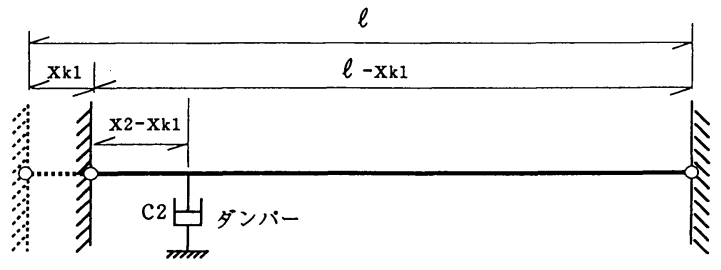

図一３等価モデルへの置換（METHOD-1）

- $x_{k 1}$ なる位置に, 粘性隇衰係数が $C_{2}$ なるオイルダン パーを設置したモデル）と等価となり，既往の設計用減 衰評価曲線を適用することによって，ケーブルに付加さ れる構造減衰を推定できることになる。なお，ここでは， 角折れ緩衝装置の上方に設置するダンパーとしてオイル ダンパーを想定していたが，粘性減衰係数が $C_{2}$ でばね 定数が $k_{2}$ なるダンパーを上方側ダンパーとして採用す る場合には, 同じ特性を有するダンパーを長さが $\ell-x_{k 1}$ なるケーブルの $x_{2}-x_{k 1}$ なる位置に設置したモデルと等 価となる。

一方, 上述した推定方法に加え, 桁側緩衝装置（設置 位置は $x_{1}$ ）のばね定数 $k_{1}$ を $x_{2}$ なる位置（ダンパーが設 置される位置) での等価なばね定数 $k_{2}^{*} に$ 変換する手法 (上述の METHOD-1 と区別するため, 以下では METHOD-2 と呼称する) を採用しても，同様にケーブ ルに付加される構造減衰を推定できると考えられる。す なわち，ばね定数が $k_{1}$ なる緩衝装置が $x_{1}$ に設置された 場合の $x_{2}$ での 1 次モード振幅を $y_{k 1}\left(x_{2}\right)$, ばね定数が $k_{2}^{*}$ なる等価ばねを $x_{2}$ なる位置に設置した場合の $x_{2}$ での 1 次モード振幅を $y_{k 2}^{*}\left(x_{2}\right)$ とすれば， $k_{1}$ なるばね定数を有 する緩衝装置の $x_{2}$ なる位置での等価ばね定数 $k_{2}^{*}$ は

$$
y_{k 1}\left(x_{2}\right)=y_{k 2}^{*}\left(x_{2}\right)
$$

なる条件から算定できる.ここで, 1 次振動モードは等 分布荷重 $p$ が作用した場合の静的変形で近似できるこ とを考慮すれば，構造力学の基礎知識を適用して得られ る $y_{k 1}\left(x_{2}\right)$ と $y_{k 2}^{*}\left(x_{2}\right)$ の解析解を式 (5)に代入して整理 することにより,等価ばね定数 $k_{2}^{*}$ の算定式として次式 が得られることとなる。 


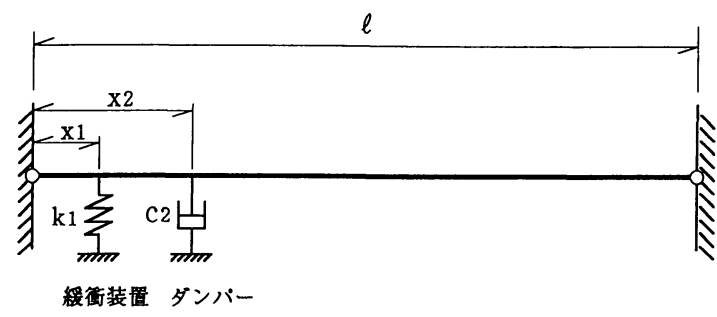

』等価モテル

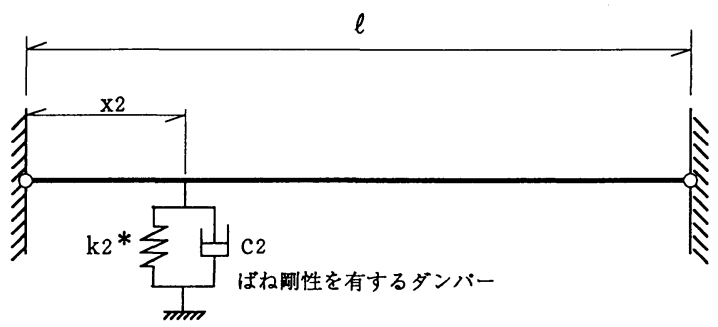

目一4＼cjkstart等価モデルへの置換（METHOD-2）

$$
k_{2}^{*}=\frac{T \ell}{x_{2}\left(\ell-x_{2}\right)} \times \frac{x_{1}}{x_{2}\left[T \ell /\left\{k_{1} x_{1}\left(\ell-x_{1}\right)\right\}+1.0\right]-x_{1}}
$$

よって, 対象とした検討モデル（下方側に緩衝装置, 上 方側にオイルダンパーが設置されたモデル）は，図一4 に示したモデル(長さ $\ell$ なるケーブルの $x_{2}$ なる位置に, ばね定数が $k_{2}^{*}$ で粘性減衰係数が $C_{2}$ なるダンパーを設 置したモデル）と等価となり，既往の設計用減衰評価曲 線を適用すれば，ケーブルに付加される構造減哀を推定 できることになる，なお，角折れ緩衝装置の上方に，粘 性減衰係数が $C_{2}$ でばね定数が $k_{2}$ なるダンパーを設置 した場合には, 粘性減衰係数が $C_{2}$, ばね定数が $k_{2}+k_{2}^{*}$ な るダンパーを長さが $\ell$ なるケーブルの $x_{2}$ なる位置に設 置したモデルと等価となり，同様に既往の設計用隇衰評 価曲線を適用すれば，ケーブルに付加される構造減衰を 推定できることとなる.

\section{（2）ダンパーを併用した場合}

本節ではより一般的な議論を展開するため, 図一 5 に 示すようにケーブル端部から $x_{1}$ と $x_{2}$ なる位置のそれぞ れに, 粘性せん断型ダンパーや高減衰ゴムに代表される ばね剛性を有するダンパー（ばねとダッシュポットから 構成されるダンパー）が設置された場合を想定する.

2 基のダンパーを併用した場合，上方側ダンパーが設 置される $x_{2}$ なる位置でのモード振幅は下方側ダンパー の寄与によって低下することから，上方側ダンパーのみ によって付加される構造隇衰（下方側ダンパーによって 付加される構造減衰を無視した值）は， $x_{2}$ なる位置に同 じばね定数と粘性減衰係数を有する 1 基のダンパーを設

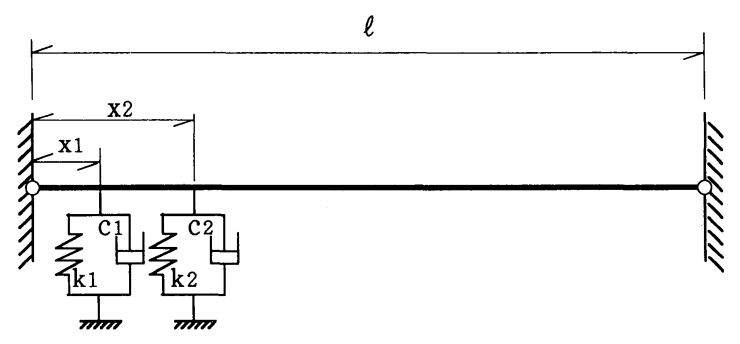

図一 5 ダンパーが併用された場合の検討モデル

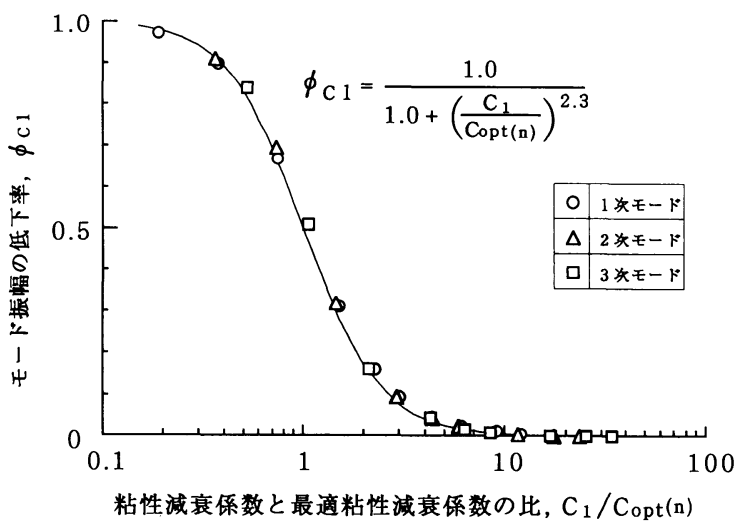

図一 6 無次元化した粘性減衰係数 $C_{1} / C_{o p t}(n)$ とモード振幅 の低下率 $\phi_{C 1}$ の関係

置した場合の構造減衰と比較して小さくなる.

ばね効果のみによるモード振幅の低下率 $\phi_{k 1}$ について はすでに式 (2)に示している. そこで, ケーブルに 1 個 のダッシュポットを設置した場合について,ダッシュ ポット設置位置におけるケーブルのモード振幅の低下率 を把握することとした．種々の構造諸元を有する長さ $100 \mathrm{~m}$ なるケーブルを対象として, ダッシュポットの取 り付け位置 $x_{1}$ と粘性減衰係数 $C_{1}$ を変化させて複素固 有值解析を実施すれば，モード振幅の低下率 $\phi_{C 1}$ （粘性 減衰係数が $C_{1}$ なる場合のモード振幅/ダッシュポット を設置しない場合のモード振幅) と $C_{1} / C_{o p t}(n)$ の関係が 図一6のように得られる.ここに, $C_{o p t}(n)$ は, ダッシュ ポットを設置した場合における $n$ 次モードの最適粘性 減衰係数である. 图一 6 より，モード次数に係わらず, ダッシュポットの取り付け点におけるモード振幅の低下 率 $\phi_{C 1}$ と $C_{1} / C_{o p t}(n)$ には, 以下の関係が成立することが わかる。

$$
\phi_{C 1}=\frac{1.0}{1.0+\left\{C_{1} / C_{o p t}(n)\right\}^{2.3}}
$$

したがって，上方側ダンパーの取り付け位置は，式(4) を参照すれば容易に推察されるように，ばね剛性を有す る下方側ダンパーの作用によって, 見かけ上, 次式で計 算される $x_{C 1 k 1}$ だけ短くなると仮定できよう. 

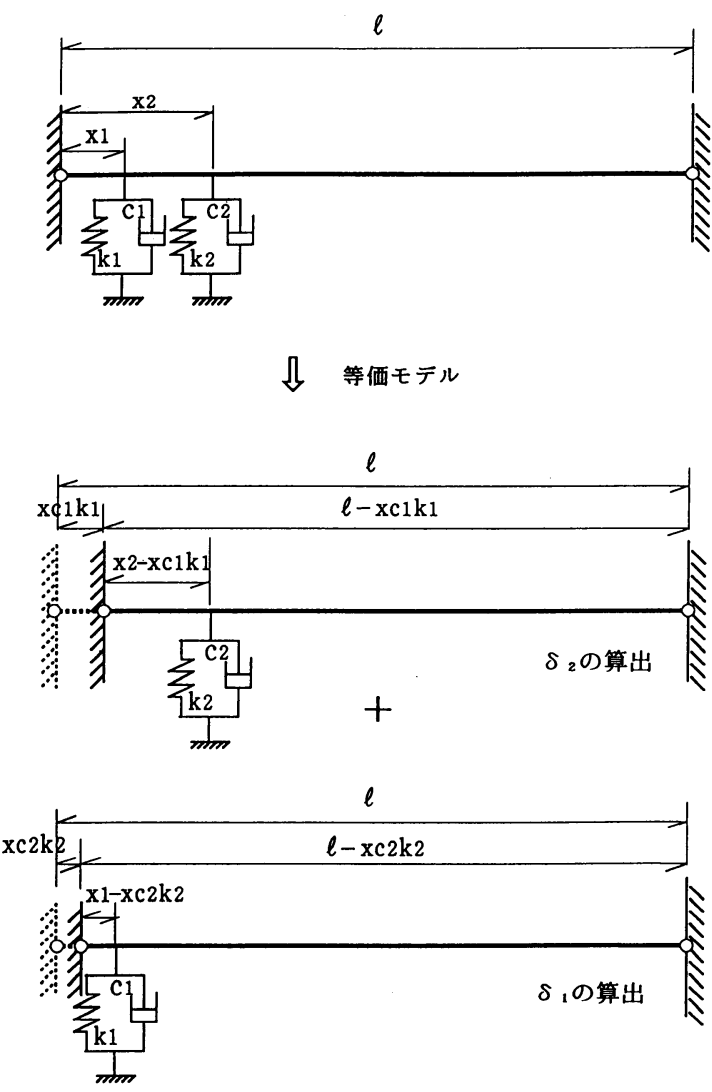

図ー7 等価モデルへの置換（併用ダンパー方式）

$x_{C 1 k 1}=\frac{n \pi x_{1}-\ell \times \sin ^{-1}\left\{\phi_{C 1} \times \phi_{k 1} \times \sin \left(n \pi x_{1} / \ell\right)\right\}}{n \pi-\sin ^{-1}\left\{\phi_{C 1} \times \phi_{k 1} \times \sin \left(n \pi x_{1} / \ell\right)\right\}}$

よって, 長さ $\ell$ なるケーブルの $x_{2}$ なる位置に設置され た上方側ダンパーによる減衰は, 同一のばね剛性を有す るダンパーを長さが $\ell-x_{c 1 k 1}$ なるケーブルの $x_{2}-x_{c 1 k 1}$ なる位置に設置した場合とほほ等価になり, 既往の設計 用減衰評価曲線を適用すればケーブルに付加される構造 対数隇衰率 $\delta_{2}$ が算出されることとなる.

同様に，上方側ダンパーの影響によって，下方側ダン パーが設置される位置での゙モド振幅は低下する．この 場合は,

$$
\sin \frac{n \pi x_{C 2 k 2}}{\ell}=\phi_{C 2} \times \phi_{k 2} \times \frac{x_{1}}{x_{2}} \times \sin \frac{n \pi x_{2}}{\ell}
$$

なる関係式から誘導した，次式で算定される $x_{C 2 k 2}$ なる 距離だけ下方側ダンパーの設置位置が短くなると仮定す る.

$$
x_{c 2 k 2}=\frac{\ell}{n \pi} \times \sin ^{-1}\left(\phi_{c 2} \times \phi_{k 2} \times \frac{x_{1}}{x_{2}} \times \sin \frac{n \pi x_{2}}{\ell}\right)
$$

ここに， $\phi_{C 2}$ と $\phi_{k 2}$ はそれぞれ次式から算定される.

$$
\phi_{C 2}=\frac{1.0}{1.0+\left\{C_{2} / C_{o p t}(n)\right\}^{2.3}}
$$

表ー $1 \quad 100 \mathrm{~m}$ ケーブルの構造諸元

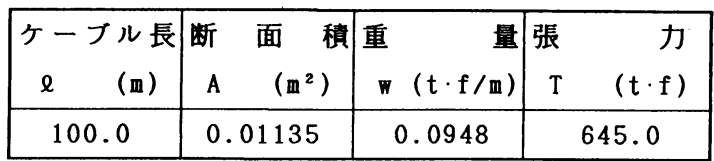

表ー2 $250 \mathrm{~m}$ ケーブルの構造諸元

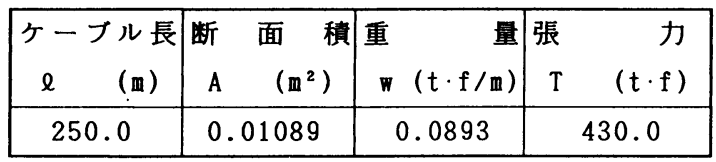

$$
\phi_{k 2}=\frac{1.0}{1.0+P_{T K 2}}
$$

よって, 長さ $\ell$ なるケーブルの $x_{1}$ なる位置に設置され た下方側ダンパーによる減衰は，同一のばね剛性を有す るダンパーを長さが $\ell-x_{C 2 k 2}$ なるケーブルの $x_{1}-x_{c 2 k 2}$ なる位置に設置した場合とほほ等価になり，既往の設計 用減衰評価曲線を適用すればケーブルに付加される構造 対数減衰率 $\delta_{1}$ が算出されることとなる.

したがって，図一7に示したように，対象とした解析 モデル（下方側と上方側にそれぞればね剛性を有するダ ンパーを設置したモデル）に付加される構造減衰は, 上 述の手順で定まる $\delta_{1}$ と $\delta_{2}$ の合計值にほほ等しくなると 推察されるが，その妥当性については次章において具体 的な数值計算例を示し，検証することとする．なお，下 方側にばね剛性を有するダンパーを，上方側にオイルダ ンパーをそれぞれ設置した場合には，式(10)において $\phi_{k 2}=1.0$ とすればよい.また，上・下方側ともオイルダ ンパーを設置した場合には, 式(8)と式(10)においてそ れぞれ $\phi_{k 1}=1.0, \phi_{k 2}=1.0$ とすれば対処できる.さらに, 式 $(8)$ において $\phi_{C_{1}}=1.0$ とすれば, 角折れ緩衝装置を 併用する場合の推定法である METHOD-1に一致する ことを付記しておく。

\section{3．提案した減衰評価手法の妥当性}

本章では, 表一 1 , 表一 2 に示すような長さがそれぞ れ $\ell=100 \mathrm{~m}$ と $\ell=250 \mathrm{~m}$ のケーブルモデルを対象とし て, 角折れ緩衝装置が施されたケーブルにダンパーを設 置した場合お゙よび 2 基のダンパーを併用した場合につい て, 前章に示した減衰評価手法に基づく構造減衰の推定 結果とより厳密な複素固有值解析による結果とを比較 し, 提案した減衰評価手法の妥当性を検証することとす る.なお, 複素固有値解析にあたっては, 分割数に依存 した解析誤差を極力小さくすることを考え, $100 \mathrm{~m}$ ケー ブルでは 100 部材に, $250 \mathrm{~m}$ ケーブルでは 250 部材に分 割するとともに, 本研究では汎用プログラムである 
表一 3 CASE-1 A に対する複素固有値解析結果と推定値 の比較

(a) 1 次モ-ド

\begin{tabular}{|c|c|c|c|c|}
\hline $\begin{array}{l}\text { 下段 側 } \\
\text { 緩衙装置 }\end{array}$ & $\begin{array}{l}\text { 上 段 側 } \\
\text { ダンバー }\end{array}$ & \multicolumn{3}{|c|}{ 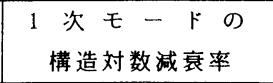 } \\
\hline $\mathrm{x}_{1}=2.0 \mathrm{~m}$ & $\mathrm{x}_{2}=5.0 \mathrm{~m}$ & \multirow{2}{*}{$\begin{array}{l}\text { 複 素 } \\
\text { 固有值 }\end{array}$} & \multicolumn{2}{|c|}{ 推 定 値 } \\
\hline $\begin{array}{c}k_{1} \\
(t f / m)\end{array}$ & $\begin{array}{c}\mathrm{C}_{2} \\
(\mathrm{tf} \cdot \mathrm{s} / \mathrm{m})\end{array}$ & & $\begin{array}{c}\text { METHOD } \\
-1 \\
\end{array}$ & $\begin{array}{c}\text { METHOD } \\
-2\end{array}$ \\
\hline \multirow{8}{*}{300.0} & 1.0 & 0.013 & 0.015 & 0.015 \\
\hline & 3.0 & 0.038 & 0.041 & 0.041 \\
\hline & 5.0 & 0.062 & 0.064 & 0.064 \\
\hline & 10.0 & 0.107 & 0.107 & 0.107 \\
\hline & 15.0 & 0.129 & 0.131 & 0.131 \\
\hline & 20.0 & 0.134 & 0.138 & 0.137 \\
\hline & 25.0 & 0.130 & 0.129 & 0.129 \\
\hline & 30.0 & 0.122 & 0.118 & 0.118 \\
\hline
\end{tabular}

(b) 3 次モード

\begin{tabular}{|c|c|c|c|c|}
\hline $\begin{array}{l}\text { 下 段 } \text { 側 } \\
\text { 緩衝装置 }\end{array}$ & $\begin{array}{l}\text { 上 段 側 } \\
\text { タンンハー }\end{array}$ & \multicolumn{3}{|c|}{$\begin{array}{c}3 \text { 次 } モ-ト の ~ \\
\text { 構造対数減衰率 }\end{array}$} \\
\hline $\mathrm{x}_{1}=2.0 \mathrm{~m}$ & $\mathrm{x}_{2}=5.0 \mathrm{~m}$ & \multirow{2}{*}{$\begin{array}{ll}\text { 複 } & \text { 素 } \\
\text { 固 有 值 }\end{array}$} & \multicolumn{2}{|c|}{ 推 定 値 } \\
\hline $\begin{array}{c}k_{1} \\
(t f / m)\end{array}$ & $\begin{array}{c}\mathrm{C}_{2} \\
(\mathrm{tf} \cdot \mathrm{s} / \mathrm{m})\end{array}$ & & $\begin{array}{c}\text { METHOD } \\
-1\end{array}$ & $\begin{array}{c}\text { METHOD } \\
-2\end{array}$ \\
\hline \multirow{8}{*}{300.0} & 1.0 & 0.037 & 0.040 & 0.039 \\
\hline & 3.0 & 0.098 & 0.097 & 0.096 \\
\hline & 5.0 & 0.131 & 0.129 & 0.128 \\
\hline & 10.0 & 0.125 & 0.120 & 0.122 \\
\hline & 15.0 & 0.097 & 0.093 & 0.095 \\
\hline & 20.0 & 0.077 & 0.073 & 0.075 \\
\hline & 25.0 & 0.063 & 0.059 & 0.060 \\
\hline & 30.0 & 0.054 & 0.049 & 0.050 \\
\hline
\end{tabular}

NASTRAN を用いて複素固有值解析（解法はデターミ ナント法）を実施することとした。また，複素固有值解 析と減衰評価手法に基づく計算は振動数が $3 \mathrm{~Hz}$ 程度以 下となるすべての鉛直振動モード（レインバイブレー ションの発現する可能性が高い振動モード）について実 施しているが，紙面の都合もあり，以下では $100 \mathrm{~m}$ ケー ブルに対しては 1 次モード $(1.291 \mathrm{~Hz})$ と 3 次モード $(3.873 \mathrm{~Hz}), 250 \mathrm{~m}$ ケーブルに対しては 1 次モード $(0.434 \mathrm{~Hz})$ と 4 次モード $(1.736 \mathrm{~Hz})$ ならびに 7 次モー ド $(3.041 \mathrm{~Hz})$ について対比することとずる.

\section{（1）角折れ緩衝装置が併用された場合}

角折れ緩衝装置が $x_{1}=2.0 \mathrm{~m}$ なる位置に施された 100 $\mathrm{m}$ ケーブルを対象に， $x_{2}=5.0 \mathrm{~m}$ なる位置にオイルダン パーを設置した場合 (CASE-1 A) および $x_{2}=4.0 \mathrm{~m}$ なる 位置に粘性せん断型ダンパーを設置した場合（CASE-1 B)のそれぞれについて，複素固有值解析結果と提案した
表一 4 CASE-1 B に対する複素固有值解析結果と推定値 の比較

(a) 1 次モ - ト

\begin{tabular}{|c|c|c|c|c|c|}
\hline $\begin{array}{ll}\text { 下 } & \text { 段 } \\
\text { 側 } \\
\text { 緩衝装置 }\end{array}$ & \multirow{2}{*}{\multicolumn{2}{|c|}{$\begin{array}{l}\text { 上 段 側 } \\
\text { ダンバー } \\
\mathrm{X}_{2}=4.0 \mathrm{~m}\end{array}$}} & \multicolumn{3}{|c|}{$\begin{array}{c}1 \text { 次 モ-トの } \\
\text { 構造対数減衰率 }\end{array}$} \\
\hline$x_{1}=2.0 \mathrm{~m}$ & & & \multirow{2}{*}{$\begin{array}{ll}\text { 複 } & \text { 素 } \\
\text { 固有値 }\end{array}$} & \multicolumn{2}{|c|}{ 推 定 值 } \\
\hline $\begin{array}{c}k_{1} \\
(t f / m)\end{array}$ & $\begin{array}{c}\mathrm{C}_{2} \\
(\mathrm{tf} \cdot \mathrm{s} / \mathrm{m})\end{array}$ & $\begin{array}{l}k_{2} \\
(t f / m)\end{array}$ & & $\begin{array}{c}\text { METHOD } \\
-1\end{array}$ & $\begin{array}{c}\text { METHOD } \\
-2\end{array}$ \\
\hline \multirow{8}{*}{300.0} & 1.0 & 4.50 & 0.007 & 0.008 & 0.008 \\
\hline & 3.0 & 13.51 & 0.020 & 0.021 & 0.020 \\
\hline & 5.0 & 22.51 & 0.030 & 0.031 & 0.030 \\
\hline & 10.0 & 45.0 & 0.047 & 0.047 & 0.046 \\
\hline & 15.0 & 67.53 & 0.055 & 0.054 & 0.053 \\
\hline & 20.0 & 90.04 & 0.058 & 0.056 & 0.057 \\
\hline & 25.0 & 112.55 & 0.059 & 0.057 & 0.058 \\
\hline & 30.0 & 135.06 & 0.057 & 0.056 & 0.058 \\
\hline
\end{tabular}

(b) 3 次モート

\begin{tabular}{|c|c|c|c|c|c|}
\hline $\begin{array}{l}\text { 下 段 側 } \\
\text { 緩衝装置 }\end{array}$ & \multirow{2}{*}{\multicolumn{2}{|c|}{$\begin{array}{l}\text { 上段 側 } \\
\text { ダンバー } \\
\mathrm{x}_{2}=4.0 \mathrm{~m}\end{array}$}} & \multicolumn{3}{|c|}{ 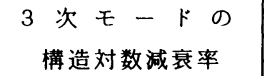 } \\
\hline $\mathrm{x}_{1}=2.0 \mathrm{~m}$ & & & \multirow{2}{*}{$\begin{array}{l}\text { 複 素 } \\
\text { 固有值 }\end{array}$} & \multicolumn{2}{|c|}{ 推 定 值 } \\
\hline $\begin{array}{c}k_{1} \\
(t f / m)\end{array}$ & $\begin{array}{c}C_{2} \\
(t f \cdot s / m)\end{array}$ & $\begin{array}{l}k_{2} \\
(t f / m)\end{array}$ & & $\begin{array}{c}\text { METHOD } \\
-1\end{array}$ & $\begin{array}{c}\text { METHOD } \\
-2\end{array}$ \\
\hline \multirow{8}{*}{300.0} & 1.0 & 12.78 & 0.019 & 0.020 & 0.020 \\
\hline & 3.0 & 38.35 & 0.045 & 0.045 & 0.042 \\
\hline & 5.0 & 63.91 & 0.057 & 0.054 & 0.053 \\
\hline & 10.0 & 127.82 & 0.060 & 0.057 & 0.058 \\
\hline & 15.0 & 191.73 & 0.053 & 0.052 & 0.053 \\
\hline & 20.0 & 255.64 & 0.045 & 0.045 & 0.047 \\
\hline & 25.0 & 319.55 & 0.039 & 0.039 & 0.040 \\
\hline & 30.0 & 383.46 & 0.035 & 0.034 & 0.034 \\
\hline
\end{tabular}

減衰評価手法による推定結果を比較した。その結果を表 -3 ，表一 4 に示す。ここに，角折れ緩衝装置のばね定 数 $k_{1}$ としては $k_{1}=300 \mathrm{tf} / \mathrm{m}$ なる值を仮定し, また, 粘性 せん断型ダンパーの等価ばね定数 $k_{2}$ と等価粘性隇衰係 数 $C_{2}$ は, 文献 10) から引用した次式において, 所定の固 有円振動数 $\omega$ と $a=0.5 \mathrm{~cm}$ なる基準振幅值を代入して 算出することとした。

$$
k_{2}=0.54 a^{-0.19} \cdot \omega^{0.95} \cdot C_{2}
$$

表一 3 と表一 4 からわかるように, METHOD-1 と METHOD-2 による推定結果は, 若干の差異はあるもの の，それぞれ複素固有值解析結果と比較的良く一致して おり，いずれの手法でも実用上ほほ十分な精度で角折れ 緩衝装置を施したケーブルにダンパーを設置した場合の 構造減衰を推定できると言える。

\section{（2）ダンパーを併用する場合}

$250 \mathrm{~m}$ ケーブルを対象として, $x_{1}=3.0 \mathrm{~m}$ と $x_{2}=10.0$ 
表一 5 CASE- 2 A に対する複素固有值解析結果と推定値 の比較

\begin{tabular}{|c|c|c|c|c|c|c|c|}
\hline \multirow{3}{*}{$\begin{array}{l}\text { 下 段 側 } \\
\text { ダンバー } \\
X_{1}=3.0 \mathrm{~m}\end{array}$} & \multirow{2}{*}{$\begin{array}{l}\text { 上段 側 } \\
\text { タンハバー }\end{array}$} & \multicolumn{6}{|c|}{ 構 造 対 数 減 衰 率 } \\
\hline & & 1 & 次 & \multicolumn{2}{|r|}{ 次 } & \multicolumn{2}{|r|}{ 次 } \\
\hline & $x_{2}=10.0 \mathrm{~m}$ & \multirow{2}{*}{$\begin{array}{l}\text { 複 素 } \\
\text { 固有值 }\end{array}$} & \multirow[b]{2}{*}{ 推定值 } & \multirow{2}{*}{$\begin{array}{l}\text { 複 素 } \\
\text { 固有值 }\end{array}$} & \multirow[b]{2}{*}{ 推定值 } & \multirow{2}{*}{$\begin{array}{l}\text { 複 素 } \\
\text { 固有值 }\end{array}$} & \multirow[b]{2}{*}{ 推定值 } \\
\hline $\begin{array}{c}C_{1} \\
(t f \cdot s / m)\end{array}$ & $\begin{array}{c}\mathrm{C}_{2} \\
(\mathrm{tf} \cdot \mathrm{s} / \mathrm{m})\end{array}$ & & & & & & \\
\hline \multirow{8}{*}{10.0} & 1.0 & 0.029 & 0.031 & 0.079 & 0.081 & 0.091 & 0.091 \\
\hline & 3.0 & 0.058 & 0.061 & 0.121 & 0.126 & 0.116 & 0.119 \\
\hline & 5.0 & 0.083 & 0.086 & 0.119 & 0.127 & 0.091 & 0.092 \\
\hline & 10.0 & 0.121 & 0.125 & 0.083 & 0.084 & 0.052 & 0.052 \\
\hline & 15.0 & 0.130 & 0.138 & 0.060 & 0.059 & 0.036 & 0.035 \\
\hline & 20.0 & 0.125 & 0.128 & 0.046 & 0.044 & 0.027 & 0.027 \\
\hline & 25.0 & 0.115 & 0.114 & 0.038 & 0.036 & 0.022 & - \\
\hline & 30.0 & 0.104 & 0.102 & 0.032 & 0.031 & 0.018 & - \\
\hline
\end{tabular}

表一 7 CASE- 2 C に対する複素固有值解析結果と推定值 の比較

\begin{tabular}{|c|c|c|c|c|c|c|c|c|}
\hline \multirow{2}{*}{\multicolumn{2}{|c|}{$\begin{array}{l}\text { 下段 側 } \\
\text { ダンバー }\end{array}$}} & \multirow{2}{*}{$\mid$\begin{tabular}{|} 
上段 側 \\
ダンバー
\end{tabular}} & \multicolumn{6}{|c|}{ 構造対数 減衰率 } \\
\hline & & & 1 & 次 & 4 & 次 & \multicolumn{2}{|l|}{7} \\
\hline \multicolumn{2}{|c|}{$X_{1}=4.0 \mathrm{~m}$} & $X_{2}=10.0 \mathrm{~m}$ & & & 複 素 & & 複 & (1) \\
\hline $\begin{array}{c}C_{1} \\
(t f \cdot s / m)\end{array}$ & $\begin{array}{c}k_{\mathrm{t}} \\
(\mathrm{tf} / \mathrm{m})\end{array}$ & $\begin{array}{c}\mathrm{C}_{2} \\
(\mathrm{tf} \cdot \mathrm{s} / \mathrm{m})\end{array}$ & 固有値 & 推足伹 & 固有値 & 推企但 & 固有値 & \\
\hline \multirow{8}{*}{10.0} & \multirow{8}{*}{100.0} & 1.0 & 0.017 & 0.018 & 0.055 & 0.051 & 0.071 & 0.064 \\
\hline & & 3.0 & 0.037 & 0.039 & 0.096 & 0.088 & 0.102 & 0.094 \\
\hline & & 5.0 & 0.055 & 0.056 & 0.103 & 0.100 & 0.086 & 0.082 \\
\hline & & 10.0 & 0.088 & 0.088 & 0.079 & 0.076 & 0.051 & 0.050 \\
\hline & & 15.0 & 0.103 & 0.105 & 0.059 & 0.056 & 0.036 & 0.034 \\
\hline & & 20.0 & 0.105 & 0.109 & 0.046 & 0.042 & 0.027 & 0.030 \\
\hline & & 25.0 & 0.101 & 0.101 & 0.038 & 0.034 & 0.022 & 0.024 \\
\hline & & 30.0 & 0.095 & 0.092 & 0.032 & 0.032 & 0.018 & - \\
\hline \multirow{8}{*}{20.0} & \multirow{8}{*}{200.0} & 1.0 & 0.015 & 0.015 & 0.045 & 0.041 & 0.057 & 0.053 \\
\hline & & 3.0 & 0.032 & 0.032 & 0.083 & 0.074 & 0.092 & 0.087 \\
\hline & & 5.0 & 0.047 & 0.047 & 0.093 & 0.088 & 0.082 & 0.080 \\
\hline & & 10.0 & 0.077 & 0.075 & 0.076 & 0.072 & 0.051 & 0.049 \\
\hline & & 15.0 & 0.092 & 0.091 & 0.058 & 0.054 & 0.036 & 0.033 \\
\hline & & 20.0 & 0.097 & 0.098 & 0.046 & 0.042 & 0.027 & 0.025 \\
\hline & & 25.0 & 0.095 & 0.095 & 0.037 & 0.033 & 0.022 & 0.026 \\
\hline & & 30.0 & 0.090 & 0.087 & 0.032 & 0.028 & 0.018 & - \\
\hline
\end{tabular}

$\mathrm{m}$ なる位置にオイルダンパーを設置した場合 (CASE-2 A) および $x_{1}=7.0 \mathrm{~m}$ と $x_{2}=10.0 \mathrm{~m}$ のきわめて近接した 位置にオイルダンパーを設置した場合 (CASE-2 B) のそ れぞれについて, 複素固有值解析結果と提案した減衰評 価手法による推定結果を比較することとした，なお，下 方側オイルダンパーの粘性減衰係数 $C_{1}$ として, CASE-2 $\mathrm{A}$ では $C_{1}=10.0 \mathrm{tf} \cdot \mathrm{s} / \mathrm{m}$ なる值を, $\mathrm{CASE}-2 \mathrm{~B}$ では $C_{1}=$ $3.5 \mathrm{tf} \cdot \mathrm{s} / \mathrm{m}$ なる值に設定することとしている. それぞれ のケースに対する比較結果を表一 5 , 表一 6 に示す。こ こに，7次モードにおいて推定值を記していない個所は 文献 10)の減衰評価曲線が適用範囲外 $\left(C_{2} / C_{o p t}(n)>\right.$ 7.0)となったことによる. 表一 5 , 表一 6 より，ケーブ ルに付加される構造減衰が最大となる付近において, 推
表一 6 CASE- 2 B に対する複素固有値解析結果と推定値 の比較

\begin{tabular}{|c|c|c|c|c|c|c|c|}
\hline 下 段 側 & 上 段 側 & \multicolumn{5}{|c|}{ 構造 対数 減衰率 } \\
\cline { 2 - 8 } タンバー \\
ダンバー
\end{tabular}

表ー8 CASE- 2 D に対する複素固有值解析結果と推定値 の比較

\begin{tabular}{|c|c|c|c|c|c|c|c|c|c|}
\hline \multirow{2}{*}{\multicolumn{2}{|c|}{$\begin{array}{l}\text { 下 段 側 } \\
\text { ダンパー }\end{array}$}} & \multirow{2}{*}{\multicolumn{2}{|c|}{$\begin{array}{l}\text { 上 段 側 } \\
\text { タンパー }\end{array}$}} & \multicolumn{6}{|c|}{ 榗造対数減衰率 } \\
\hline & & & & 1 & 次 & 4 & 次 & 7 & 次 \\
\hline \multicolumn{2}{|c|}{$x_{1}=4.0 \mathrm{ar}$} & \multicolumn{2}{|c|}{$x_{2}=10.0 m$} & \multirow{2}{*}{$\begin{array}{ll}\text { 複 } & \text { 素 } \\
\text { 固有値 }\end{array}$} & \multirow{2}{*}{ 推定值 } & \multirow{2}{*}{$\begin{array}{l}\text { 複 素 } \\
\text { 固有値 }\end{array}$} & \multirow[b]{2}{*}{ 推定値 } & \multirow{2}{*}{$\begin{array}{l}\text { 複 素 } \\
\text { 固有値 }\end{array}$} & \multirow[b]{2}{*}{ 推定値 } \\
\hline $\begin{array}{c}C_{1} \\
(t f \cdot s / m)\end{array}$ & $\begin{array}{c}k_{1} \\
(t f / m)\end{array}$ & $\begin{array}{c}C_{2} \\
(t f \cdot s / m)\end{array}$ & $\begin{array}{c}k_{2} \\
(t f / m)\end{array}$ & & & & & & \\
\hline \multirow{8}{*}{2.5} & \multirow{8}{*}{25.0} & 1.0 & \multirow{4}{*}{10.0} & 0.012 & 0.014 & 0.046 & 0.046 & 0.072 & 0.067 \\
\hline & & 3.0 & & 0.030 & 0.033 & 0.091 & 0.089 & 0.109 & 0.102 \\
\hline & & 5.0 & & 0.047 & 0.049 & 0.103 & 0.104 & 0.090 & 0.088 \\
\hline & & 10.0 & & 0.079 & 0.080 & 0.080 & 0.079 & 0.053 & 0.057 \\
\hline & & 15.0 & \multirow{4}{*}{30.0} & 0.062 & 0.060 & 0.055 & 0.054 & 0.035 & 0.034 \\
\hline & & 20.0 & & 0.070 & 0.069 & 0.044 & 0.042 & 0.027 & 0.025 \\
\hline & & 25.0 & & 0.073 & 0.073 & 0.037 & 0.034 & 0.022 & 0.021 \\
\hline & & 30.0 & & 0.073 & 0.072 & 0.031 & 0.028 & 0.018 & 0.018 \\
\hline \multirow{8}{*}{10.0} & \multirow{8}{*}{100.0} & 1.0 & \multirow{4}{*}{10.0} & 0.012 & 0.014 & 0.042 & 0.040 & 0.057 & 0.052 \\
\hline & & 3.0 & & 0.027 & 0.029 & 0.076 & 0.071 & 0.087 & 0.080 \\
\hline & & 5.0 & & 0.040 & 0.043 & 0.088 & 0.084 & 0.079 & 0.078 \\
\hline & & 10.0 & & 0.067 & 0.068 & 0.074 & 0.073 & 0.050 & 0.050 \\
\hline & & 15.0 & \multirow{4}{*}{30.0} & 0.055 & 0.053 & 0.052 & 0.047 & 0.034 & 0.036 \\
\hline & & 20.0 & & 0.063 & 0.061 & 0.043 & 0.039 & 0.027 & 0.026 \\
\hline & & 25.0 & & 0.067 & 0.065 & 0.036 & 0.034 & 0.022 & 0.021 \\
\hline & & 30.0 & & 0.068 & 0.066 & 0.031 & 0.028 & 0.018 & 0.017 \\
\hline
\end{tabular}

定值は複素固有值解析結果に比べ若干大きくなっている ものの, 両者の結果はおおむね良く一致していることが 理解されよう。

次に, $x_{1}=4.0 \mathrm{~m}$ なる位置にばね剛性を有する下方側 ダンパーを設置するとともに, $x_{2}=10.0 \mathrm{~m}$ なる上方側に オイルダンパーを設置した場合 (CASE-2 C) ならびにば ね剛性を有するダンパーを設置した場合 (CASE-2 D) に ついても, 同椂に複素固有值解析結果と提案した減衰評 価手法による推定結果を比較することとした，その結果 を表一 7 ，表一 8 に示す。表一 7 ，表一 8 より，ばね剛 性を有するダンパーを上方側ダンパーや下方側ダンパー として採用した場合にも, 推定值は複素固有值解析結果 と比較的良く一致していることが容易に理解されよう.

以上の検討結果より, 下方側ダンパーの寄与で上方側 
ダンパーの設置位置が, また, 上方側ダンパーの寄与で 下方側ダンパーの設置位置がそれぞれ短くなると仮定し て, 従来の設計用隇衰評価曲線から計算した上方側ダン パーのみと下方側ダンパーのみによる構造減衰を重ね合 わせる本減衰評価手法はほほ妥当であり, 実務上の有用 性も高いと言えよう。なお，本文で提示した以外の数多 くのケースについて検討した結果, 本減衰評価手法は,

下方側ダンパーと上方側ダンパーの設置位置が $x_{1} / x_{2} \leqq$ 0.8 で, かつ下方側オイルダンパーの粘性減衰係数が $C_{1} / C_{o p t}(n) \leqq 5.0$ (下方側にばね剛性を有するダンパーを 設置した場合, その最適粘性減衰係数を $C_{o p t}^{k}(n)$ とすれ ば, $\left.C_{1} / C_{o p t}^{k}(n) \leqq 5.0\right)$ なる場合にもほほ十分な精度で, ケーブルに付加される構造減衰を推定できたことを付記 しておく.

\section{4. 併用ダンパー方式の特徵と产の設計上の留 意点}

1 本のケーブルに 2 基のダンパーを設置する併用ダン パー方式については鶴見つばさ橋での実施例があるのみ で, 本方式の特徵や設計上の留意点については未だ十分 に解明されているとは言えない，そこで，本章では提案 した減衰評価手法を適用してケーススタディを実施し, 併用ダンパー方式の特徵とその設計上の留意点について 検討することとした.

ケーブル制振用ダンパーとしては種々の方式が開発さ れており， 2 基のダンパーを設置する場合にも多数の組 み合わせが想定できる。しかしながら，ケーブル振動を 誘起させる風の励振力は鉛直方向成分が卓越しているこ とから, 下方側ダンパー（オイルダンパーでは 1 対）に よって鉛直方向と水平方向に構造減衰を付加すれば，上 方側では鉛直方向のみを対象として構造減衰を増加させ れば良いと考えられる.すなわち, 1 個のオイルダンパー を上方側の鉛直方向のみに設置することも可能であり， この場合にはオイルダンパーの粘性減衰係数が小さいほ どダンパー本体とその設置用架台が小型化されることと なる.このような観点から, 本ケーススタディでは, 上・ 下方側ともオイルダンパーを採用した場合, 粘性せん断 型ダンパー（下方側）とオイルダンパー（上方側）を併 用した場合および高減衰ゴム(下方側) とオイルダンパー (上方側)を併用した場合のそれぞれに着目することとし た.

なお，併用ダンパー方式を採用する場合にも，景観に 対する配慮から下方側ダンパーは高欄や自動車防護椓高 さを越えない位置に設置することが望ましいと言える。 そこで, 本検討では, 取り付け位置を $x_{1}=6.0 \mathrm{~m}$ とした 場合に，下方側ダンパーは高闌や自動車防護桹高さと同 程度の高さに設置されるものと仮定した. 一方, 上方側

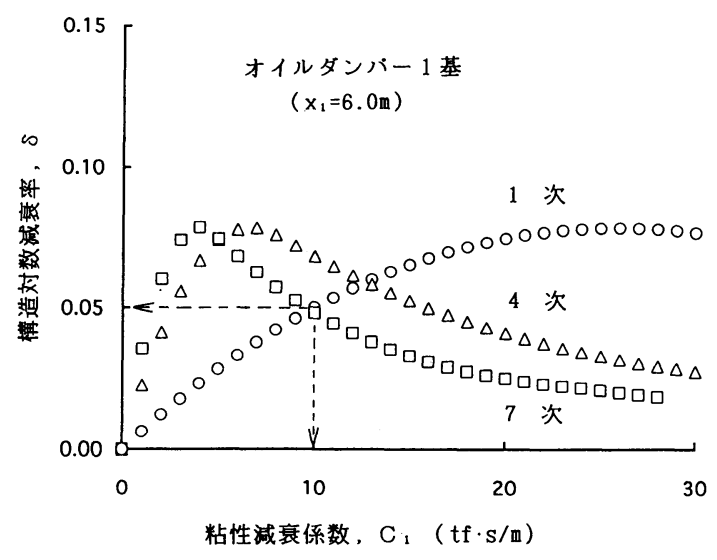

図一8 1 基のオイルダンパーによって付加される構造減衰

ダンパーについては高欄や自動車防護棶高さを越える $x_{2}=10.0 \mathrm{~m}$ なる位置に設置するものとしたが, ダンパー 本体および設置用架台をできるだけ小さくして景観に配 慮するとの観点から, 上方側オイルダンパーの粘性減衰 係数は, 後述するよう基本的に $3.0 \mathrm{tf} \cdot \mathrm{s} / \mathrm{m}$ なる值よりも 小さく設定することとした.

\section{（1）上・下方側ともオイルタンパーを採用する場合}

対象としたケーブルは表一 2 に示した構造諸元を有す る $250 \mathrm{~m}$ ケーブルである. まず最初に, 高欄や自動車防 護桶高さと同程度の高さにダンパーを設置した場合の減 衰付加特性を把握するため, $x_{1}=6.0 \mathrm{~m}$ なる位置に 1 個 のオイルダンパーを鉛直方向に設置した場合の構造隇衰 を推定することとした. 1 次モードと 4 次モードならび に 7 次モードに対する推定結果を図一 8 に示す. 図一 8 より, $C_{1}=10.0 \mathrm{tf} \cdot \mathrm{s} / \mathrm{m}$ 程度の粘性減衰係数を有するオ イルダンパーを設置すれば, 1 次モード〜 7 次モードに は少なくとも $\delta=0.05$ 程度以上の構造減衰が付加され ることがわかる，ただし，オイルダンパー方式では複素 固有值解析結果と実橋ケーブル試験で測定された実測值 には一般に差異が生じ, 設計にあたっては 0.5 なる減衰 付加効率を採用するのが通常である ${ }^{8)}$. すなわち, 実務設 計にあたっては，1次モード〜 7次モードに付加される 構造対数減衰率は $\delta=0.025$ 程度以上であると認識しな ければならないが, 本節では簡単のため減衰付加効率に よる影響を無視して議論することとする。

併用ダンパー方式の基本的な特性を把握するため, 下 方側オイルダンパーの粘性減哀係数 $C_{1}$ を上述した $C_{1}$ $=10.0 \mathrm{tf} \cdot \mathrm{s} / \mathrm{m}$ (理論上, 1 次〜 7 次モードの構造対数減 衰率が少なくとも $\delta=0.05$ 程度以上となる粘性隇衰係 数）なる值に設定し，上方側オイルダンパーの粘性減衰 係数 $C_{2}$ を種々変化させてケーブルに付加される構造減 衰を推定することとした. 1 次モードと 4 次モードなら 

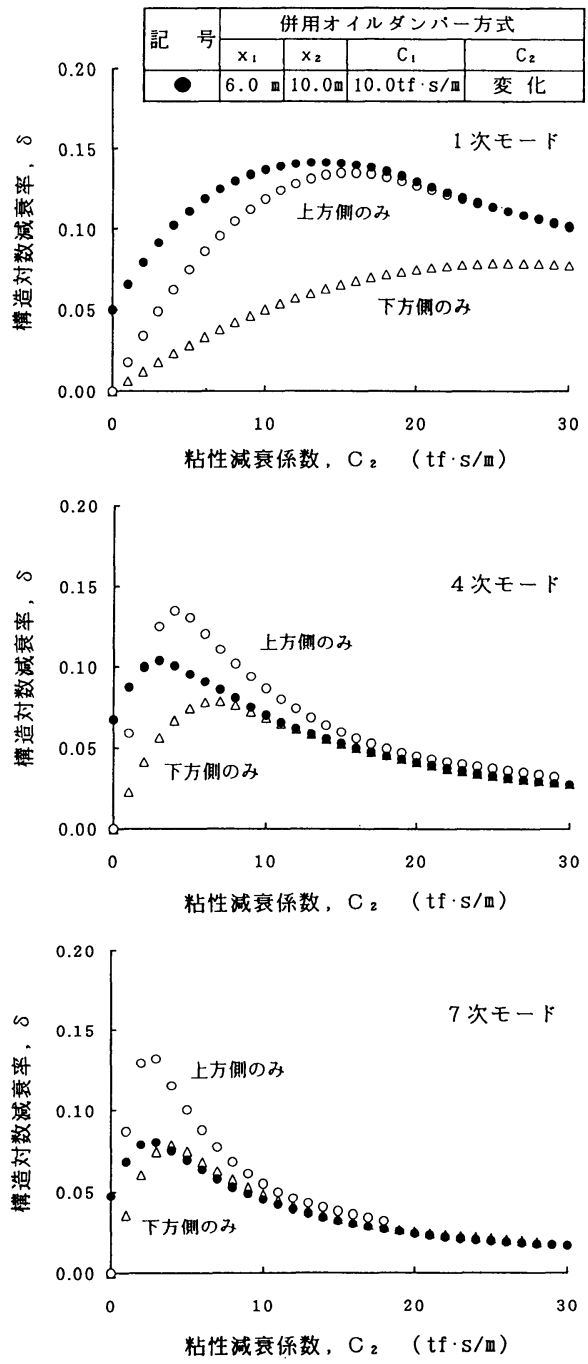

図一 9 併用オイルダンパー方式 $\left(C_{1}=10.0 \mathrm{tf} \cdot \mathrm{s} / \mathrm{m}\right.$ に固定 $)$ によって付加される構造減衰

びに 7 次モードに対する結果を図一 9 に示す。なおここ の図には下方側 $\left(x_{1}=6.0 \mathrm{~m}\right)$ のみにオイルダンパーを設 置した場合 (図中の $\triangle$ 記号) と上方側 $\left(x_{2}=10.0 \mathrm{~m}\right)$ の みにオイルダンパーを設置した場合（図中の○記号）の 結果も参考までに併記している. 図一9ょり，併用ダン パー方式によって各振動モードに付加される構造減衰の 最大值はモード次数の増加とともに低下し，1 次モード では上方側 $\left(x_{2}=10.0 \mathrm{~m}\right)$ のみにオイルダンパーを設置 した場合の最大值に, また, 7 次モードでは下方側 $\left(x_{1}=\right.$ $6.0 \mathrm{~m} ）$ のみにオイルダンパーを設置した場合の最大值 に，それぞれほほ等しくなっていることがわかる，すな わち，図一7に示した等価モデルからも推察されるよう に, 併用ダンパー方式を採用しても, 各振動モードに付 加される構造減衰の最大值は, 上方側のみにオイルダン

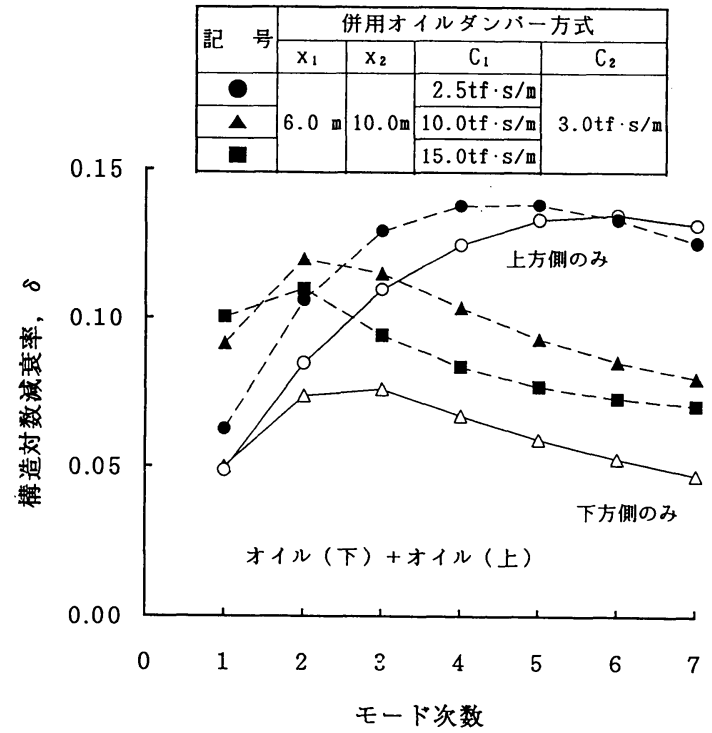

図一10 併用オイルダンパー方式 $\left(C_{2}=3.0 \mathrm{tf} \cdot \mathrm{s} / \mathrm{m}\right.$ に固定 $) に$ よって付加される構造隇衰

パーを設置した場合の最大值と同程度かそれ以下の値に なることを十分認識していなければならない.

しかしながら，同じく図一 9 から，上方側オイルダン パーの粘性減衰係数を適切に設定すれば, 併用ダンパー 方式によって，上方側 $\left(x_{2}=10.0 \mathrm{~m}\right)$ のみに同じ粘性隇 衰係数を有するオイルダンパーを設置した場合よりも， 大きな減衰付加効果が得られていることがわかる。 そこ で，上・下方側オイルダンパーの粘性減衰係数をそれぞ れ変化させて各振動モードに付加される構造減衰を算定 し，併用ダンパー方式の特徵と設計上の留意点について 検討することとした，ただし，併用ダンパー方式では， 上方側ダンパーが高欄や自動車防護耚高さを越える位置 に設置されることから，景観をできるだけ損なわないよ う配慮する必要がある。すなおち，上方側 $\left(x_{2}=10.0 \mathrm{~m}\right)$ のみにオイルダンパーを設置するとした場合，粘性減衰 係数を $C_{2}=6.0 \mathrm{tf} \cdot \mathrm{s} / \mathrm{m}$ に設定すれば, 1 次〜 7 次モード に $\delta=0.05$ 程度以上の構造減衰が付加されることとな るが, ダンパー本体やダンパー設置用架台が大きくなり すぎ，景観上の問題から採用が困難になることも予想さ れる。しかしながら，上方側オイルダンパーの設置高さ が同じであってもオイルダンパーの粘性隇衰係数が小さ いほどダンパー本体や設置用架台は小さく設計でき, 景 観に対しても少なからず配慮できることとなる．このよ うな理由から，本ケーススタディでは，上方側オイルダ ンパーの粘性減衰係数として $3.0 \mathrm{tf} ・ \mathrm{~s} / \mathrm{m}(6.0 \mathrm{tf} \bullet \mathrm{s} / \mathrm{m} \times$ 1/2）以下なる值に設定することとした.

上方側オイルダンパーの粘性減衰係数 $C_{2} を C_{2}=3.0$ $\mathrm{tf} \cdot \mathrm{s} / \mathrm{m}$ に, 下方側オイルダンパーの粘性減衰係数 $C_{1}$ を 


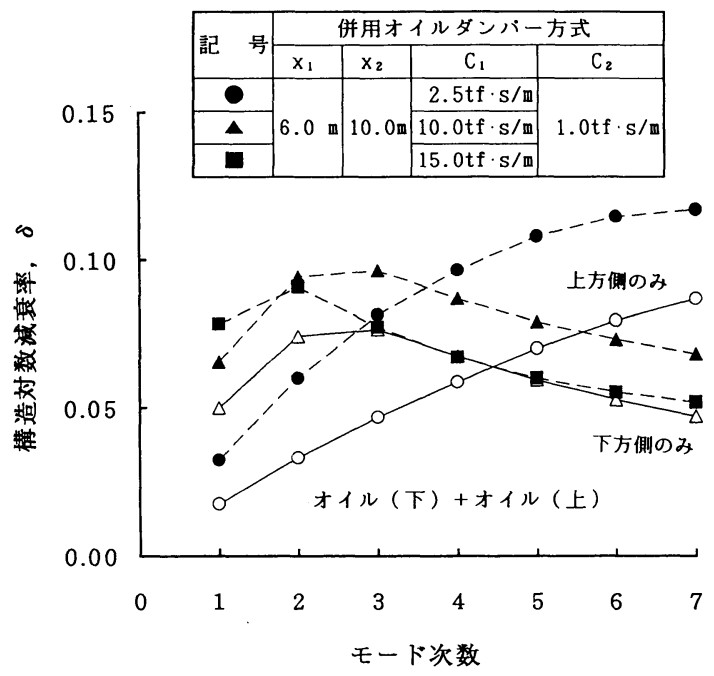

図-11 併用オイルダンパー方式 $\left(C_{2}=1.0 \mathrm{tf} \cdot \mathrm{s} / \mathrm{m}\right.$ に固定 $)$ に よって付加される構造減衰

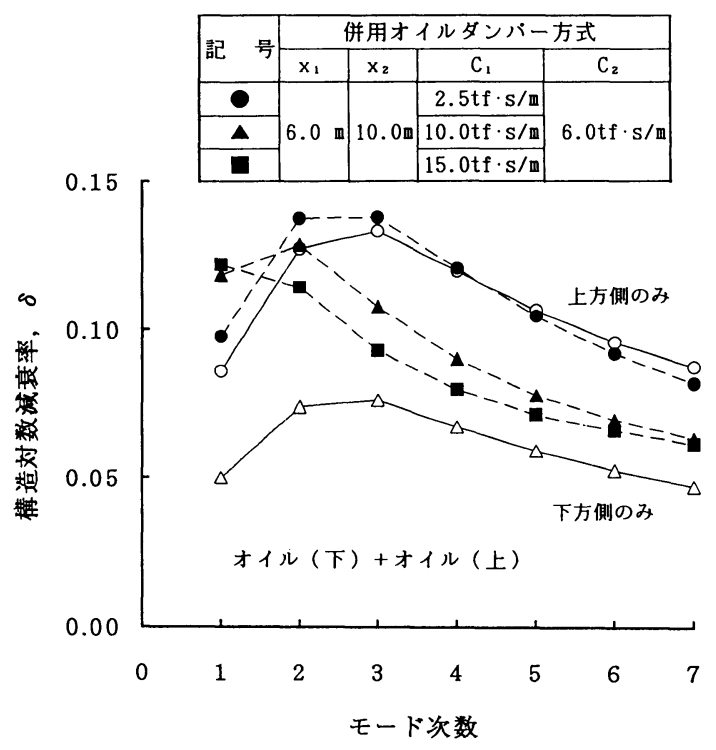

図一12 併用オイルダンパー方式 $\left(C_{2}=6.0 \mathrm{tf} \cdot \mathrm{s} / \mathrm{m}\right.$ に固定 $)$ に よって付加される構造隇衰

$C_{1}=2.5 \mathrm{tf} \cdot \mathrm{s} / \mathrm{m}, 10.0 \mathrm{tf} \cdot \mathrm{s} / \mathrm{m}, 15.0 \mathrm{tf} \cdot \mathrm{s} / \mathrm{m}$ なる值に変化 させてケーブルに付加される構造減衰を算出した。 その 結果を図一10に示す.なお, 図一10には下方側 $\left(x_{1}=6.0\right.$ $\mathrm{m} ）$ のみに $C_{1}=10.0 \mathrm{tf} \cdot \mathrm{s} / \mathrm{m}$ なるオイルダンパーを設置 した場合（図中の $\triangle$ 記号）および上方側 $\left(x_{2}=10.0 \mathrm{~m}\right)$ のみに $C_{2}=3.0 \mathrm{tf}$ なるオイルダンパーを設置した場合 (図中の○記号)の結果も付記している. 図一10からわか るように, 併用ダンパー方式 (図中の黒ぬり記号) では, 下方側 $\left(x_{1}=6.0 \mathrm{~m}\right)$ のみに $C_{1}=10.0 \mathrm{tf} \cdot \mathrm{s} / \mathrm{m}$ なるオイル ダンパーを設置した場合と比較してょり大きな構造隇衰

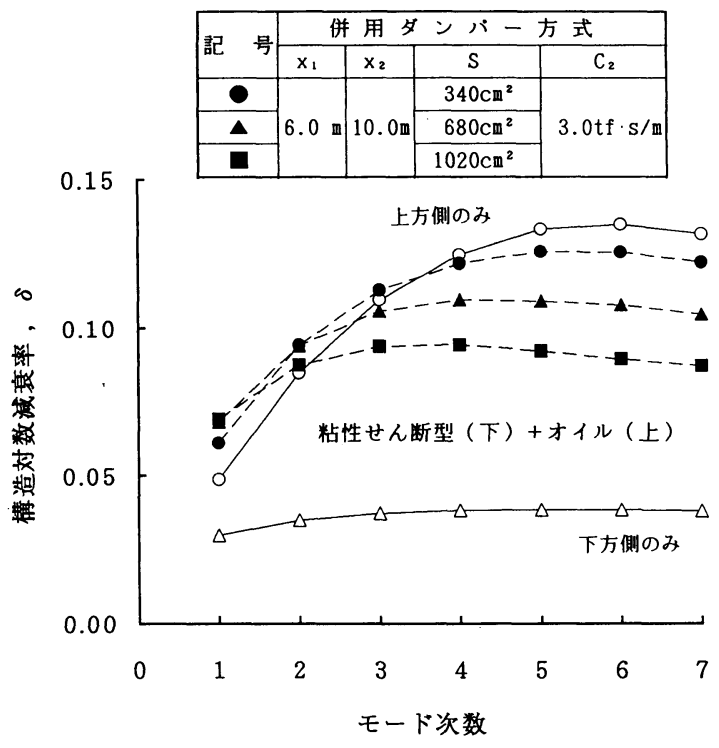

図一13 併用ダンパー方式 $\left(C_{2}=3.0 \mathrm{tf} \cdot \mathrm{s} / \mathrm{m}\right.$ に固定 $)$ にって 付加される構造減衰 (粘性せん断型ダンパー十オイル ダンパー；減衰付加効率の差異を無視）

が付加されており，本方式の有用性が認められる結果が 得られている。しかしながら，たとえば，下方側オイル ダンパーの粘性隇衰係数が $C_{1}=10.0 \mathrm{tf} ・ \mathrm{~s} / \mathrm{m}$ なる併用ダ ンパー方式 (図中のム記号) では, 上方側 $\left(x_{2}=10.0 \mathrm{~m}\right)$ のみに $C_{2}=3.0 \mathrm{tf} \cdot \mathrm{s} / \mathrm{m}$ なるオイルダンパーを設置した 場合と比較し，3 次モードまではより大きな構造隇衰が 付加されているものの，4次モード以上では逆に低下す る結果となっている。それゆえ，併用ダンパー方式を採 用するにあたっては, 下方側ダンパーの粘性隇衰係数と して適切な值を設定し, 高次モードの構造減衰が耐風設 計上の所要値を下回らないよう配慮する必要があると言 える。なお，図一11は上方側オイルダンパーの粘性減衰 係数をきわめて小さな $C_{2}=1.0 \mathrm{tf} \cdot \mathrm{s} / \mathrm{m}$ なる值とした場 合の結果であるが, 図一10 と図一11を比較すればわかる ように, 付加される構造減衰は $C_{2}=3.0 \mathrm{tf} \cdot \mathrm{s} / \mathrm{m}$ なる場合 よりも若干小さくなっているものの同様に併用ダンパー 方式の有用性が認められている.すなわち, 長大なケー ブルではサグ(たるみ)の影響で 1 次モードの構造減衰が もともと大きいという知見 ${ }^{11)}$ を加味して構造隇衰の所要 值の大きさを適切に設定すれば，十分に採用できる制振 案であると言えよう.

一方, 上方側オイルダンパーの粘性減衰係数を $C_{2}=$ $6.0 \mathrm{tf} \cdot \mathrm{s} / \mathrm{m}$ とした併用ダンパー方式についても補足的 に検討した。 その結果を図一12 に示す. 図一12 からわか るように，この場合にはオイルダンパーを併用したこと による有用性は比較的少なく, とりわけ, 下方側オイル ダンパーの粘性減衰係数が $C_{1}=10.0 \mathrm{tf} \cdot \mathrm{s} / \mathrm{m}$ より大きい 


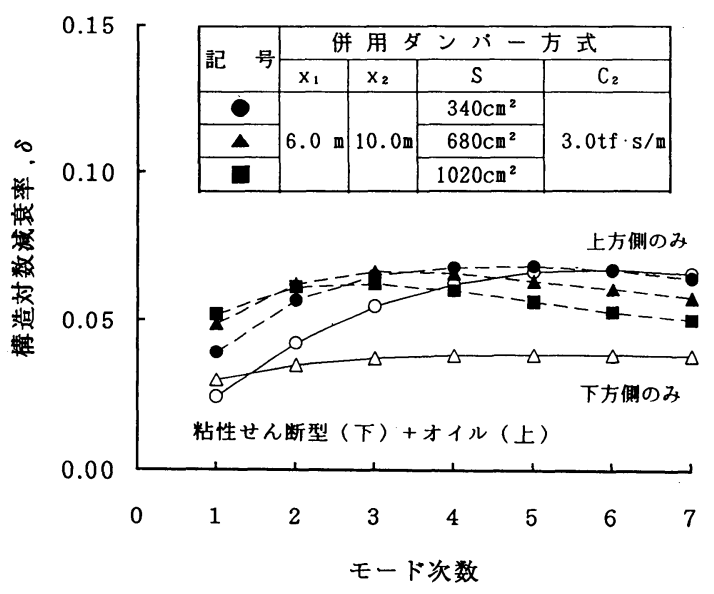

図一14 併用ダンパー方式 $\left(C_{2}=3.0 \mathrm{tf} \cdot \mathrm{s} / \mathrm{m}\right.$ に固定 $)$ によって 付加される構造減衰 (粘性せん断型ダンパー十オイル ダンパー；減衰付加効率の差異を考慮）

場合には 3 次モード以上の構造隇衰が大幅に低下する結 果となっている，すなわち，併用ダンパー方式では，景 観上からも, また, 減衰付加特性からも, 上方側オイル ダンパーの粘性減衰係数を, 上方側のみに 1 個のオイル ダンパーを設置するとした場合の所要粘性減衰係数より かなり小さく設定することがきわめて重要であると言え る.

\section{（2）粘性せん断型ダンパー(下方側)とオイルダンパー （上方側）を併用する場合}

前節と同じく, 対象とする振動は $250 \mathrm{~m}$ ケーブルの 1 次〜 7 次モードである.まず, $x_{1}=6.0 \mathrm{~m}$ なる位置に粘性 せん断型ダンパーのみを設置するとした場合, 文献 10) を参照して粘性せん断を期待する断面積 $S$ を $S=680$ $\mathrm{cm}^{2}$ に設定すれば, $t=40^{\circ} \mathrm{C}$ なる温度条件下で 1 次〜 7 次 モードには $\delta=0.03$ 程度以上の構造隇衰が付加される こととなる。そこで, 粘性せん断を期待する断面積 $S$ を $S=340 \mathrm{~cm}^{2}\left(680 \mathrm{~cm}^{2} \times 0.5\right), 680 \mathrm{~cm}^{2}, 1020 \mathrm{~cm}^{2}(680$ $\left.\mathrm{cm}^{2} \times 1.5\right)$ とそれぞれ仮定して等価粘性隇衰係数と等価 ばね定数を算出するとともに，上方側オイルダンパーの 粘性減衰係数を $3.0 \mathrm{tf} \cdot \mathrm{s} / \mathrm{m}$ に設定して,ケーブルに付加 される構造減衰を比較することとした。その結果を図 一13 に示す。なお，この図には，下方側 $\left(x_{1}=6.0 \mathrm{~m}\right)$ の みに $S=680 \mathrm{~cm}^{2}$ なる粘性せん断型ダンパーを設置した 場合（図中の $\triangle$ 記号）および上方側 $\left(x_{2}=10.0 \mathrm{~m}\right)$ のみ に $C_{2}=3.0 \mathrm{tf} \cdot \mathrm{s} / \mathrm{m}$ なるオイルダンパーを設置した場合 （図中の○記号）の結果も付記している.

図一13 からわかるように，粘性せん断型ダンパー（下 方側）とオイルダンパー（上方側）を併用する方式（図 中の黒ぬり記号) でも, 下方側 $\left(x_{1}=6.0 \mathrm{~m}\right)$ のみに $S=$ $680 \mathrm{~cm}^{2}$ なる粘性せん断型ダンパーを設置した場合と比

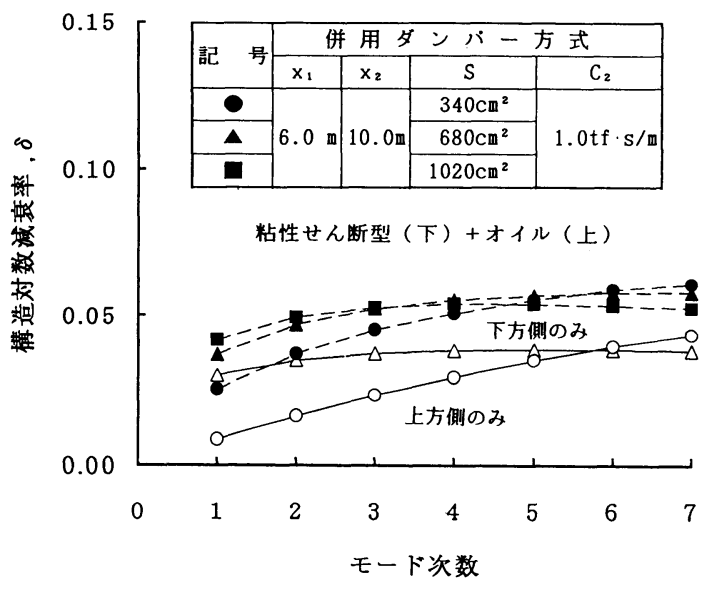

図-15 併用ダンパー方式 $\left(C_{2}=1.0 \mathrm{tf} \bullet \mathrm{s} / \mathrm{m}\right.$ に固定 $)$ によって 付加される構造減衰 (粘性せん断型ダンパー十オイル ダンパー；減衰付加効率の差異を考慮）

較してょり大きな構造減衰が付加されており, 併用方式 の有用性が認められる結果が得られている。しかしなが ら，たとえば，下方側に $S=680 \mathrm{~cm}^{2} な る$ 粘性せん断型ダ ンパーを設置した併用方式では，上方側 $\left(x_{2}=10.0 \mathrm{~m}\right)$

のみに $C_{2}=3.0 \mathrm{tf} \cdot \mathrm{s} / \mathrm{m}$ なるオイルダンパーを設置した 場合と比較して, 1 次モードと 2 次モードの構造減衰は わずかに増加する程度であるのに対し, 高次モードの構 造減衰は逆にかなり低下する結果となっていることがわ かる.

ところで, オイルダンパーの減衰付加効率は 0.5 程度 であると考えられているのに対して, 粘性せん断型ダン パーでは等価粘性減衰係数と等価ばね定数を適切に評価 すれば，ほほ 1.0 なる減衰付加効率が採用できることが 知られている ${ }^{10)}$. 異なる特性を有するダンパーを併用し た場合における減衰付加効率については今後の検討を待 たなければならない.しかしながら,ここでは上述の知 見から，下方側の粘性せん断型ダンパーによる減衰寄与 分 (2 章に示した手順で算出される $\delta_{1}$ ) はそのままで, 上方側のオイルダンパーによる減衰寄与分（2 章に示し た手順で算出される $\left.\delta_{2}\right)$ のみに 0.5 なる減衰付加効率を 乗じて，異なる特性を有するダンパーを併用した場合の 減衰付加特性を評価することとした。 なお, 複素固有值 解析では, 併用ダンパー方式による構造減衰（理論值） を正確に計算できるが，上・下方側ダンパーによるそれ ぞれの減衰寄与は算定できない. したがって，2 章に示 した減衰評価手法は異なる特性（減衰付加効率）を有す るダンパーを併用した場合の検討に，とりわけ有用なも のであることを述べておきたい.

上方側オイルダンパーの粘性隇衰係数が $C_{2}=3.0 \mathrm{tf} ・$ $\mathrm{s} / \mathrm{m}$ なる場合について減衰付加効率の差異を考慮し, 併 用ダンパー方式による減衰付加特性を検討すれば, 図 


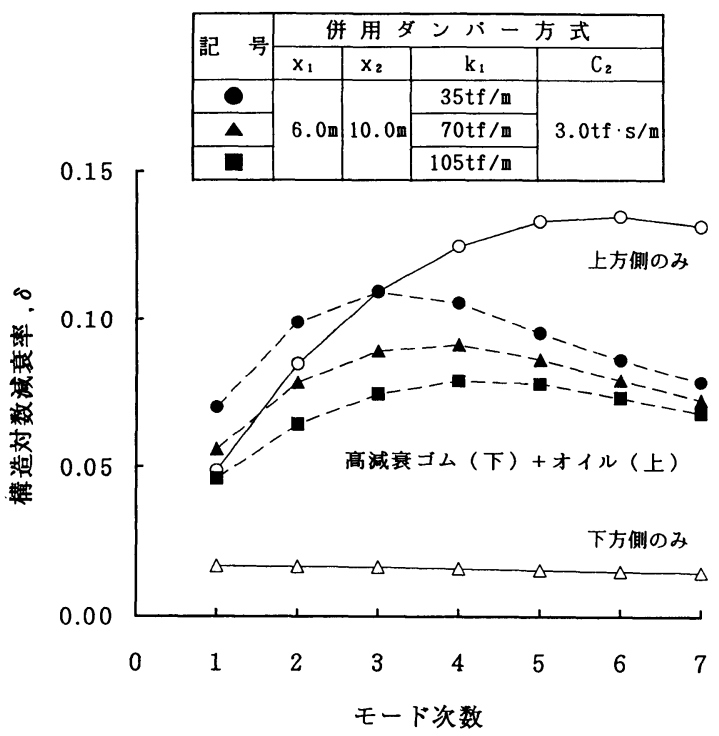

図-16 併用ダンパー方式 $\left(C_{2}=3.0 \mathrm{tf} \cdot \mathrm{s} / \mathrm{m}\right.$ に固定 $)$ によって 付加される構造減衰 (高減衰ゴム十オイルダンパー; 減衰付加効率の差異を無視)

-14に示す結果が得られる. 図一14より, 減衰付加効率 の差異を考慮した場合, 粘性せん断型ダンパーとオイル ダンパーを併用する方式は, 上方側のみにオイルダン パーを設置する従来方式（図中の○記号）と比較し, 低 次モードに付加される構造減衰が耐風設計上有意な程度 まで増加することがわかる。 また，粘性せん断を期待す る断面積 $S$ を適切に選定すれば, 高次モードにおける構 造減衰の低下割合いもきわめて小さくなることが理解で きよう.なお，図一15 は上方側オイルダンパーの粘性減 衰係数をきわめて小さい $C_{2}=1.0 \mathrm{tf} ・ \mathrm{~s} / \mathrm{m}$ とした場合の 結果であるが, 図一14 と図一15 を比較すればわかるよう に付加される構造減衰は $C_{2}=3.0 \mathrm{tf} \cdot \mathrm{s} / \mathrm{m}$ なる場合より も若干小さくなっているものの同様に併用ダンパーとし ての有用性が認められている。すなわち，長大なケーブ ルではサグの影響で 1 次モードの構造減衰がもともと大 きいという知見 ${ }^{11)}$ を加味して構造隇衰の所要值の大きさ を適切に設定すれば，十分に採用できる制振案であると 言えよう。

\section{（3）高滅衰ゴム (下方側) とオイルダンパー（上方側） を併用する場合}

対象とする振動は同様に $250 \mathrm{~m}$ ケーブルの 1 次〜 7 次モードである. 高減衰ゴムの $n$ 次モードに対する等価 粘性減衰係数 $C_{e}(n)$ は一般に次式で表示される ${ }^{1)}$.

$$
C_{e}(n)=\frac{1}{\omega_{n}} \times \frac{4 \gamma}{4+\gamma^{2}} \times k_{e}
$$

ここに, $\omega_{n}$ は $n$ 次モードの固有円振動数, $k_{e}$ は高減衰 ゴムの等価ばね定数である.また, $\gamma$ は内部摩擦係数であ

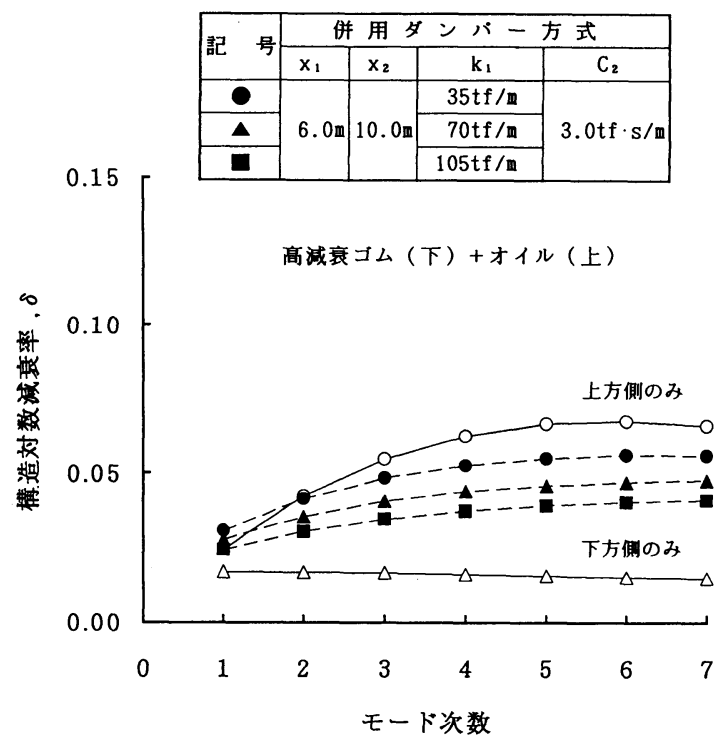

図-17 併用ダンパー方式 $\left(C_{2}=3.0 \mathrm{tf} \cdot \mathrm{s} / \mathrm{m}\right.$ に固定 $)$ によって 付加される構造減衰 (高減衰ゴム十オイルダンパー； 減衰付加効率の差異を考慮)

り, 本検討では $\gamma=0.5$ なる值を採用することとする. まず， $x_{1}=6.0 \mathrm{~m}$ なる位置に高減衰ゴムのみを設置す るとした場合, 文献 1) を参照して最適ばね定数を決定す れば $k_{e}\left(=k_{1}\right)=70 \mathrm{tf} / \mathrm{m}$ なる值が得られる.すなわち, $k_{1}$ $=70 \mathrm{tf} / \mathrm{m}$ なる高減衰ゴムを $x_{1}=6.0 \mathrm{~m}$ なる位置に設置 すれば， 1 次〜 7 次モードにはほほ等しい $\delta=0.017$ 程 度の構造減衰が付加されることとなる，そこで，下方側 に設置する高減衰ゴムのばね定数として $k_{1}=35 \mathrm{tf} / \mathrm{m}$ $(70 \mathrm{tf} / \mathrm{m} \times 0.5), 70 \mathrm{tf} / \mathrm{m}, 105 \mathrm{tf} / \mathrm{m}(70 \mathrm{tf} / \mathrm{m} \times 1.5)$ と それぞれ仮定して式(14) から等価粘性減衰係数を算出す るとともに，上方側オイルダンパーの粘性減衰係数を $3.0 \mathrm{tf} / \mathrm{m}$ に設定して,ケーブルに付加される構造減衰を 比較することとした．その結果を図一16に示す．なお， この図には, 下方側 $\left(x_{1}=6.0 \mathrm{~m}\right)$ のみに $k_{1}=70 \mathrm{tf} / \mathrm{m}$ な る高隇衰ゴムを設置した場合（図中の $\triangle$ 記号）および上 方側 $\left(x_{2}=10.0 \mathrm{~m}\right)$ のみに $C_{2}=3.0 \mathrm{tf} \cdot \mathrm{s} / \mathrm{m}$ なるオイルダ ンパーを設置した場合（図中の○記号）の結果も付記し ている.

図一16からわかるように, 高隇衰ゴムとオイルダン パー（上方側）を併用する方式（図中の黒ぬり記号）で も, 下方側 $\left(x_{1}=6.0 \mathrm{~m}\right)$ のみに $k_{1}=70 \mathrm{tf} / \mathrm{m}$ なる高減衰 ゴムを設置した場合と比較してょり大きな構造減衰が付 加されており, 併用方式の有用性が認められる結果が得 られている. しかしながら, 最も効果が認められた $k_{1}=$ $35 \mathrm{tf} / \mathrm{m}$ なる高減衰ゴムを併用した場合でも，1 次モー ドと 2 次モードの構造減衰は, 上方側 $\left(x_{2}=10.0 \mathrm{~m}\right)$ の みに $C_{2}=3.0 \mathrm{tf} \cdot \mathrm{s} / \mathrm{m}$ なるオイルダンパーを設置した場 合と比較して, 1 次モードと 2 次モードの構造減衰はわ 
ずかに増加する程度であるのに対し, 高次モードの構造 減衰はモード次数の増加とともに大幅に低下する結果と なっている.

ところで, 高減衰ゴム方式では粘性せん断型ダンパー と同様に，ほほ 1.0 なる減衰付加効率が採用できること が知られている，そこで，下方側の高減衰ゴムによる減 衰寄与分（2 章に示した手順で算出される $\delta_{1}$ ) はそのま まで, 上方側のオイルダンパーによる減衰寄与分（2 章 に示した手順で算出される $\left.\delta_{2}\right)$ のみに 0.5 なる減衰付加 効率を乗じて, 異なる特性を有するダンパーを併用した 場合の減衰付加特性を評価することとした，上方側オイ ルダンパーの粘性減衰係数が $C_{2}=3.0 \mathrm{tf} \cdot \mathrm{s} / \mathrm{m}$ なる場合 の結果を図一17に示す，図一17より，高隇衰ゴム(下方 側）とオイルダンパー（上方側）を併用した場合の構造 減衰は, 減衰付加効率の差異を考慮しても, 上方側のみ に $C_{2}=3.0 \mathrm{tf} \cdot \mathrm{s} / \mathrm{m}$ なるオイルダンパーを設置した場合 に付加される值（図中の○記号）とほとんど同じかそれ 以下であることがわかる，それゅえ，高隇衰ゴム（下方 側）とオイルダンパー（上方側）を併用する方式は，上・ 下方側ともオイルダンパーとした場合や粘性せん断型ダ ンパー（下方側）とオイルダンパー（上方側）を併用し た場合と比較して減衰付加特性は小さく, ケーブルのサ グ変化に伴う 2 次応力の低減を期待すべき時に採用する 併用方式であると言えよう。

\section{5.まとめ}

本論文は， 1 本のケーブルに 2 基のダンパーを設置す る併用ダンパー方式の減衰評価手法とこの方式を採用す るにあたっての設計上の留意点について検討したもので ある. 得られた主要な結果を以下にまとめる.

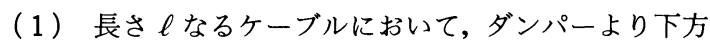
の $x_{1}$ なる位置に桁側角折れ緩衝装置が併用された場合, ダンパーの設置位置 $x_{2}$ は角折れ緩衝装置の影響で本文 に提示した $x_{k 1}$ なる距離だけ短くなると仮定できる。し たがって,ダンパーのばね定数を $k_{2}$, 粘性減衰係数を $C_{2}$ とすれば, 対象とした検討モデルは, 長さが $\ell-x_{k 1}$ なる ケーブルの $x_{2}-x_{k 1}$ なる位置に同じ特性を有する上方側 ダンパーを設置したモデルと等価となる.一方, 対象と した検討モデルは, 本文で提示した算定式から, 等価ば ね定数 $k_{2}^{*}$ を計算すれば, 長さが $\ell$ なるケーブルの $x_{2}$ な る位置に, ば衫定数が $k_{2}^{*}+k_{2}$ で粘性減衰係数が $C_{2}$ なる ダンパーを設置したモデルとも等価となる.

（2）長さ $\ell$ なるケーブルの $x_{1}$ と $x_{2}$ なる位置にばね 剛性を有するダンパーが併用された場合, 上方側ダン パーの設置位置は下方側ダンパーの影響で本文に提示し た $x_{c 1 k 1}$ なる距離だけ, また, 下方側ダンパーの設置位置 は上方側ダンパーの影響で $x_{C 2 k 2}$ なる距離だけ, それぞ
れ短くなると仮定できる。したがって，上方側ダンパー のばね定数を $k_{2}$, 粘性減衰係数を $C_{2}$ とすれば, 併用方式 における上方側ダンパーのみによる寄与は, 同じばね定 数と粘性減衰係数を有する 1 個のダンパーを長さが $\ell$ 一 $x_{C 1 k 1}$ なるケーブルの $x_{2}-x_{C 1 k 1}$ なる位置に設置した 場合とほほ等価となる。また，下方側ダンパーのばね定 数を $k_{1}$, 粘性減衰係数を $C_{1}$ とすれば, 併用方式における 下方側ダンパーのみによる寄与は，同じばね定数と粘性 減衰係数を有する 1 個のダンパーを長さが $\ell-x_{c 2 k 2}$ な るケーブルの $x_{1}-x_{c 2 k 2}$ なる位置に設置したモデルとほ ぼ等価となる。

（3）以上の各等価モデルに対して既往の設計用減衰評 価曲線（1 本のケーブルに 1 個のダンパーを設置した場 合の減衰評価曲線）を適用すれば，角折れ緩衝装置が施 されたケーブルにダンパーを設置した場合および 1 本の ケーブルに 2 基のダンパーを併用した場合の構造減衰を それぞれ推定できることとなる。そこで，長さが $100 \mathrm{~m}$ と $250 \mathrm{~m}$ のケーブルを対象として複素固有值解析結果 と本手法による推定結果を比較したところ良好な一致が 得られ，本文に提示した減衰評価手法は実務上の有用性 もきわめて高いものであることがわかった.

(4) 提案した減衰評価手法を適用してケーススタディ $\left(250 \mathrm{~m}\right.$ ケーブルの $x_{1}=6.0 \mathrm{~m}$ と $x_{2}=10.0 \mathrm{~m}$ にそれ れ上・下方側ダンパーを設置したケース）を実施し，併 用ダンパー方式の特徵と設計上の留意点について検討し た。その結果，上・下方側にそれぞれオイルダンパーを 設置した場合に付加される構造減衰は，下方側のみに才 イルダンパーを設置した場合と比較して明らかに増加す るものの, 各モードに付加される構造減衰の最大值は, 上方側のみにオイルダンパーを設置した場合の最大值と 同程度かそれ以下になることがわかった.しかしながら， 上・下方側オイルダンパーの粘性隇衰係数をそれぞれ適 切に設定すれば，上方側のみに同じ粘性減衰係数を有す るオイルダンパーを設置した場合と比較し, 高次モード の構造減衰は幾分低下するものの, 低次モードの構造減 衰は耐風設計上有意な程度まで増加できることがわかっ た.

（5）粘性せん断型ダンパー(下方側) とオイルダンパー （上方側）を併用する方式でも，上・下方側ダンパーの諸 特性を適切に設定するとともに減衰付加効率の差異を考 慮すれば，上方側のみに同じ粘性減衰係数を有するオイ ルダンパーを設置する従来方式と比較し, 低次モードの 構造隇衰は耐風設計上有意な程度まで増加できることが わかった。

（6）高減衰ゴム (下方側）とオイルダンパー（上方側） を併用する方式は，上・下方側ともオイルダンパーとし た場合や粘性せん断型ダンパー（下方側）とオイルダン パー（上方側）を併用した場合と比較して減衰付加特性 
は小さく, ケーブルのサグ変化に伴う 2 次応力の低減を 期待すべき時に採用する併用方式であることがわかつ た。

近年における斜張橋の長径間化と施工実績は目覚まし く,その機能美から本形式はますます盛んに建設されて いくものと予想される. それゆえ, 風によるケーブル振 動とその制振に関する検討も今までにも増して重要とな り, 大規模な長大斜張橋では, 空力的対策に加え, 1 本 のケーブルに 2 基のダンパーを設置する併用ダンパー方 式を対策案の一つとして検討する機会が増加するものと 推察される.このような状況のもと, 併用ダンパー方式 の減衰評価手法と設計上の留意点について詳述した本文 が, ケーブル制振対策を検討する実務技術者にとって有 用な技術資料になることを心より願う次第である.

\section{参考文献}

1）米田昌弘：斜張橋ケーブルの風による振動とその制御, 土木学会・第 2 回振動制御コロキウム（PART A, 構造 物の振動制御 ( 2 )), pp.21-41, 1993 年 8 月.

2) 鳥野 清, 堤 一, 麻生稔彦, 吉村 健, 井上朝登, 田 中千秋, 佐々木伸幸, 中谷真二 : 荒津大橋の振動特性と ケーブルダンパーの制振効果, 九州技報, pp.23-30, 1989 年 6 月.

3）米田昌弘, 前田研一, 伊関治郎, 下田郁夫：ケーブル制 振用粘性せん断型ダンパの開発, 日本機械学会論文集 (C 編), 58 巻 555 号, pp.47-52, 1992 年 11 月.
4) Nakamura, A., Kasuga, A, and H. Arai : The Effects of Mechanical Dampers on Stay Cables with High -damping Rubber, Proc. of 10 th U.S.-Japan Bridge Engineering Workshop, Nevada, May, 1994.

5）藤原 亨, 植田利夫, 小林義和：斜張橋ケーブルの角折 れ緩衝材による制振効果, 土木学会第 47 回年次学術講演 会講演概要集, I-247, pp.670-671，1992 年 9 月.

6）松本 勝, 北沢正彦, 石崎 浩, 小川一志, 斎藤 通, 下土居秀樹：東神戸大橋の耐風設計, 橋梁と基礎, Vol. 25, No. 5, pp.33-43, 1991 年 5 月.

7）下里哲弘, 岡田昌澄, 村上琢哉：鶴見航路橋（仮称）の ケーブル振動実験, 土木学会第 49 回年次学術講演会講演 概要集, I-605, pp.1208-1209，1994 年 9 月.

8）烏野 清, 北川正一, 堤 一, 井上朝登, 中谷真二 : 斜 張橋ヶーブル制振用ダンパーの簡易設計法, 構造工学論 文集, Vol. 37 A, pp.789-798, 1991 年 3 月.

9）藤野陽三, Pacheco M. Benito, Sulekh Ajai：ダンパー をつけた斜張橋ケーブルの減衰評価曲線, 橋梁と基礎, Vol. 26, No. 4, pp.41-45, 1992 年 4 月.

10）米田昌弘, 下田郁夫：ケーブル制振用粘性せん断型ダン パーの減衰付加特性に及ほすすばね剛性の影響とその設計 用減衰評価曲線, 土木学会論文集, 第 480 号/VI-21, pp. $77-86,1993$ 年 12 月.

11) H. Yamaguchi and Fujino, Y.: Modal damping of Flexural oscillation in Suspended Cables, Proc. of JSSC, No. 386/I-8, pp.197-205, October, 1987.

(1994.9.8 受付)

\title{
ON THE SIMPLIFIED METHOD FOR ESTIMATING MODAL DAMPING IN STAY CABLE WITH TWO TYPES OF DAMPERS AND ITS APPLICATION TO VIBRATION CONTROL DESIGN
}

\author{
Masahiro YONEDA, Hideyuki MOCHIZUKI and Hideki SETOUCHI
}

In recent years, wind-induced cable vibrations of cable-stayed bridge have been observed, and phenomena of these have become a major problem in wind engineering. This paper deals with the vibration control of stay cable by installation of two types of dampers. The authors have derived a practical estimation method for the modal damping in stay cable with dampers. Several examples demonstrating the application of the proposed method are also presented for the cable model with the length of $100 \mathrm{~m}$ and $250 \mathrm{~m}$. From these results, some useful informations for the vibration control of stay cable by installation of two types of dampers are obtained. 